FOR SUPPORT OF RESEARCH ENTITLED:

\title{
MECHANISTIC STUDIES OF CARBON MONOXIDE REDUCTION
}

GRANT NO. DE-FG02-85ER13323-A003

PRINCIPAL INVESTIGATOR:

SOCLAL SECURITY NO.:

PHONE:

AMOUNT FUNDED:

TIME PERIOD OF REPORT:

DOE PROJECT OFFICER:
Gregory L. Geoffroy

Department of Chemistry

The Pennsylvania State University

University Park, PA 16802

400-64-5958

(814)865-9591

$\$ 362,400$

Jan 1, 1988 - Dec 31, 1990

Steven A. Butter

Division of Chemical Sciences

Office of Basic Energy Sciences

U.S. Department of Energy

Germantown, MD 20545

DOE CONTRACTING OFFICER: Jerry L. Zimmer

Acquisition and Assistance Operations Branch

U.S. Department of Energy, AAOD.1C

Chicago Operations Office

9800 S. Cass Avenue

Argonne, IL 60439

DOEADMINISTRATOR: L Lisa Rogers

U.S. Department of Energy, AAOD-1C

Chicago Operations Office

9800 S. Cass Avenue

Argonne, IL 60439

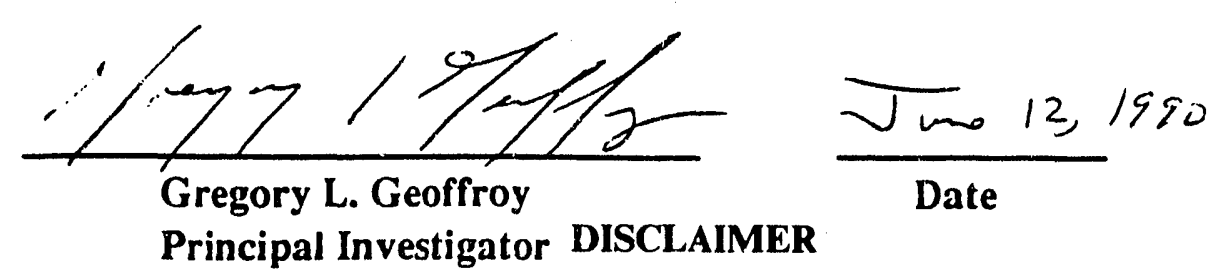

This report was prepared as an account of work sponsored by an agency of the United States Government. Neither the United States Gnvernment nor any agency thereof, nor any of their employees, makes any warranty, express or implied, or assumes any legal liability or responsibility for the accuracy, completeness, or usefulness of any information, apparatus, product, or process disclosed, or represents that its use would not infringe privately owned rights. Reference herein to any specific commercial product, process, or service by trade name, trademark, manufacturer, or otherwise does not necessarily constitute or imply its endorsement, recommendation, or favoring by the United States Government or any agency thereof. The views and opinions of authors expressed herein do not necessarily state or reflect those of the United State, Government or any agency thereof. 


\section{Personnel}

A. Postdoctoral Fellows:

Name

John Sheridan

Noël Lugan

Kuang-Lieh Lu

B. Graduate Students

Name

Sherri Bassner

Sung-Hwan Han

Phillip Macklin

Chad Mirkin

Beth Handwerker

David Ramage

Jeong-Sip Song

Toni Snsad

Colleen Kelly

Michael Terry
Undergrad.

U. Bristol, U.K.

U. Paul Sabatier, Toulouse, France Nat'l Taiwan U.

Undergrad. School

Goucher College

Seoul National U.

IJ.S. Military Acad.

Dickinson College

Franklin \& Marshali

U. South Alabama

Seoul National U.

Worcester College

U. Richmond

U. Richmond
Ph.D. School

U. Bristol

U. Paul Sabatier, Toulouse, France Nat'l Taiwan U.
Present Location

Rutgers U.,

CNRS, Toulouse

Academia Sinica

C. Indargraduate Scholars:

Name

Sonbinh Nguyen

Anne Kaplin

Kevin Ashliman

Heather Beckman
B.S.

1990, PSU

in progress

in progress

in progress
Ph.D. Present Location

1987

1988

1988

1989

1989

in prog.

in prog.

in prog.

in prog.

in prog.
Airr Products Co.

Korea Inst. Sci. \& Tech. Instructor, U.S.

Military Academy

Postdoc, MIT (Wrighton)

ARCO Chemical

D. Collaborators:

Dr. Robert Whittle, Penn State X-ray crystallographer

Prof. Amold Rheingold, University of Delaware, X-ray crystallographer

Prof. Nathan Viswanathan, Penn State Fayette Campus.

Dr. Duarie Dombek., Union Carbide Corporation.

\section{Publications Resulting from this DOE Grant}

1. Geoffroy, G. L.; Bassner, S. L. "Interaction of ketenes with Organometallic Compounds.

Ketene, Ketenyl; and Ketenylidene Complexes". Adv. Organomet. Chem., 1988, $28,1$.

2. 'Bassner, S. L.; Geoffroy, G. L.; Rheingold, A. L. "Generation and Reactivity of Ketene Ligands on Triosmium Clusters". Polyhedron 1988, ㄱ, 791. 
3. Rheingold, A. L.; Staley, D. L.; Han, S.-H.; Geoffroy, G. L.

"Di- $\mu$-carbonyl-nonacarbonyl- $\mu_{4}-\left(\alpha-\alpha^{\prime}-\eta\right.$-diphenylacetylene $)-\left(\mu_{4}\right.$

-diphenylnitrone)tetraruthenium(4 Ru-Ru)". Acta Cryst. 1988, $44,570$.

4. Han, S.-H.; Nguyen, S. T.; Geoffroy, G. L.; Rheingold, A. L. "Hexaruthenium and Heptaruthenium Clusters Possessing $\mu_{4}$-Imido Ligands". Organometallics, 1988, $\underline{7}$, 2034-2038.

5. Sheridan, J. B.; Johnson, J. R.; Handwerker, B. M.; Geoffroy, G. L.; Rheingold, A. L. " $\alpha$-Ketoacyl Complexes of Manganese Formed by Insertion of $\mathrm{CO}$ into a Manganese-Acyl Bond and by Nitrite Addition to a Manganese Carbyne Complex". Organometallics, 1988, 7, 2404.

6. Han, S.-H.; Geoffroy, G. L.; Dombek, B. D.; Rheingold, A. L. "Equilibria within the $\mathrm{Ru}_{3}(\mathrm{CO})_{12} /$ Halide System" Inorg. Chem. 1988, 27, 4355.

7. Han, S. H.; Geoffroy, G. L. "Halide Promotion of the Formation and Carbonylation of $\mu_{3}$-Imido Ligands. Relevance to the Halide Promotion of Nitroaromatic Carbonylation Catalysis" Polyhedron 1988, Z, 2331-2339.

8. Geoffroy, G. L.; Sheridan, J. B.; Bassner, S. L., Kelley, C. "Migratory-insertion of carbon monoxide into metal-acyl bonds" Pure Appl. Chem. 1989, 61, 1723-1729.

9. Mirkin, C. A.; Lu, K.-L., Geoffroy, G. L. "Ferrapyrrolinone and Ferraazetine Complexes Formed from the Reaction of $\mathrm{Fe}_{2}\left(\mu-\mathrm{CH}_{2}\right)(\mathrm{CO})_{8}$ with Phosphinimines" J.Am. Chem. Soc. $1989,111,7279-7281$.

10. Han, S.-H.; Song, J.-S.; Macklin, P. D.; Nguyen, S. T.; Geoffroy, G. L.; Rheingold, A. L. "Further Studies of Cluster-Bound Imido Ligands. Imido-Acyl Coupling and Promotion of the Formation and Carbonylation of Imido Ligands by Halides" Organometallics 1989, $\underline{8}$, 2127-2138

11. Bassner, S. L.; Sheridan, J. B.; Kelley, C.; Geoffroy, G. L. "Reactivity of the $\alpha$-Ketoacyl Ligand in Cp'(L)(NO)Mn-C $\{\mathrm{O}\} \mathrm{C}\{\mathrm{O}\}$ Tol with Electrophiles, Nucleophiles, and Alkynes" Organometallics 1989, $\underline{8}, 2121-2126$.

12. Mirkin, C. A.; Lu, K.-L.; Geoffroy, G. L.; Rheingold, A. L. "Fluorine-Substituted Ferracyclopentadiene Complexes with an Unprecedented Fluorine Bridge between Boron and Carbon" J. Am. Chem. Soc. 1990, 112, 461-462.

13. Pilato, R. S.; McGettigan, C.; Geoffroy, G. L.; Rheingold, A. L.; Gelb, S. J. "tert-Butylnitroso Complexes. Structural Characterization of $\mathrm{W}(\mathrm{CO})_{5}\left(\mathrm{~N}(\mathrm{O}) \mathrm{Bu}^{\mathrm{l}}\right)$ and $\left[\overline{\mathrm{CpFe}}(\mathrm{CO})\left(\mathrm{PPh}_{3}\right)\left(\mathrm{N}(\mathrm{O}) \mathrm{Bu}^{2}\right)\right]^{+}$Organometallics 1990, $2,312-317$.

14. Lugan, N.; Kelley, C.; Terry, M. R.; Geoffroy, G. L.; Rheingold, A. L. "Conjugate-Addition of a Chiral Manganese Acetylide Complex to Epoxides, Vinylketones, and Heterocumulenes" J.Am.Chem. Soc., 1990, 112, 3220.

15. Mirkin, C. A.; Lu, K.-L.; Snead, T. E.; Geoffroy, G. L.; Rheingold, A. L. "Synthesis of Substituted Pyridinones from the Combination of $\mathrm{Fe}_{2}\left(\mu-\mathrm{CH}_{2}\right)(\mathrm{CO})_{8}$ with Phosphinimines and Alkynes" J. Am. Chem. Soc., 1990, 112, 2809.

16. Mirkin, C. A.; Geoffroy, G. L.; Macklin, P. D.; Rheingold, A. L. "Synthesis and Characterization of the Heterobinuclear $\mu$-Methylene Complex $(\mathrm{CO})_{4} \mathrm{FePt}\left(\mathrm{PPh}_{3}\right)_{2}\left(\mu-\mathrm{CH}_{2}\right)$ " Inorg. Chim. Acta, 1990, 170, 11-15.

17. Song, J.-S.; Han, S.-H., Nguyen, S. T.; Geoffroy, G. L.; Rheingold, A. L. "Reactivity of Fe and $\mathrm{Ru}_{3} \mu_{3}$-Phenylimido Clusters with Alkynes, Allene, and Cyclohexadiene" Organometallics, in press. 
18. Stufkens, D. J.; Sheridan, J. B.; Geoffroy, G. L. "IR Evidence for the Formation of an $\eta^{2}(\mathrm{C}, \mathrm{O})-\alpha$-ketoacyl Complex Upon Low Temperature

Photolysis $\left(\eta-\mathrm{C}_{5} \mathrm{H}_{4} \mathrm{Me}\right)(\mathrm{CO})(\mathrm{NO}) \mathrm{Mn}-\mathrm{C}\{\mathrm{O}\} \mathrm{C}\{\mathrm{O}\}$ Tol" Inorg. Chem., submitted for publication. 


\section{PROGRESS REPORT}

(Jan 1, $1988-\operatorname{Apr} 1,1990)$

The research supported by this grant has focussed on three themes:

1. Oxidatively-induced double carbonylation reactions to form $\alpha$-ketoacyl complexes and studies of the reactivity of the resulting compounds.

2. Mechanistic studies of the carbonylation of nitroaromitics to form isocyanates, carbamates, and ureas.

3. Studies of the formation and reactivity of unusual metallacycles and alkylidene ligands supported on binuclear iron carbonyl fragments.

The progress made in each of these areas during the current grant period is summarized in the following paragraphs.

I. Oxidatively-Induced Double Carbonylation Reactions. Migratory insertion of CO into metal-alkyl bonds is a well established reaction of fundamental importance in organometallic chemistry and is an essential step in many catalytic and stoichiometric reactions. In contrast, migratory-insertion of $\mathrm{C} \rho$ into metal-acyl bonds to form $\alpha$-ketoacyl ligands has long been recognized as an unfavorable reaction ${ }^{1}$ and one with no definitive examples until the work summarized below was first reported. 2.3 .

In late 1987 we discovered an example of the migratory-insertion of $\mathrm{CO}$ into a metal acyl bond induced by a unique oxidation/NO addition reaction sequence. ${ }^{2,3}$ This work initially began while we were investigating aspects of the chemistry of the carbyne complex 1 . Upon treating this species with [PPN] $\left[\mathrm{NO}_{2}\right]$ at low temperature, we observed the formation of carbene complex $\underline{2}$ through the addition of $\mathrm{NO}_{2}^{-}$to the electrophilic carbyne carbon, analogous to the many other nucleophiles known to add to this carbon. ${ }^{4}$ However, upon warming above $-10^{\circ} \mathrm{C}$ this species decayed to form the $\alpha$-ketoacyl complex $\underline{3}$ (eq. 1) which was isolated in high yield and was spectroscopically and crystallographically characterized, Figure $1 .{ }^{2}$ While investigating the
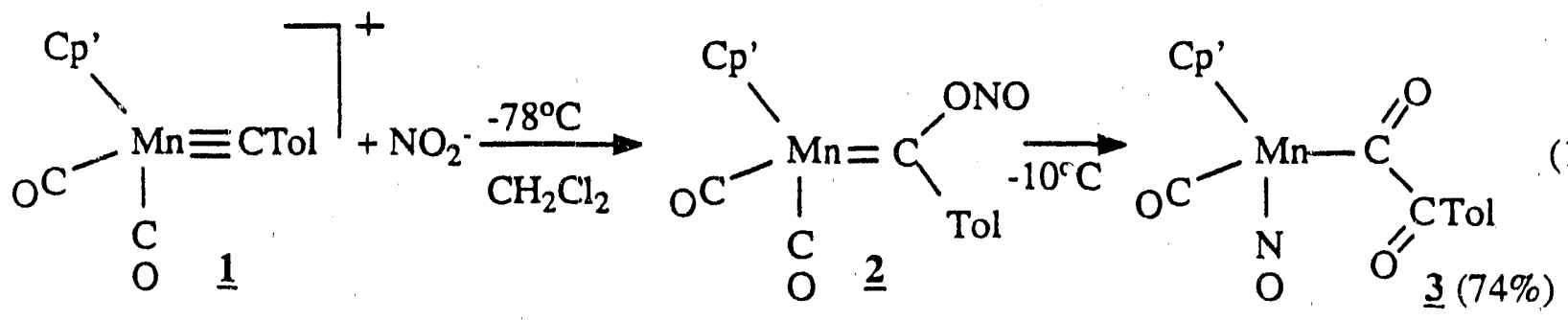

mechanism of the latter transformation, we considered the possibility that carbene complex $\underline{\mathbf{2}}$ could decay to give free $\mathrm{NO}$ and the $17 \mathrm{e}^{-}$acyl complex $\mathrm{Cp}^{\prime}(\mathrm{CO})_{2} \mathrm{Mn}-\mathrm{C}(\mathrm{O}) \mathrm{Tol}, \underline{4}$, which could then recombine with NO to yield the $\alpha$-ketoacyl complex $\underline{\mathbf{3}}$ (see below). To test this possibility, complex 4 was independently generated by oxidation of the known acyl complex 
Figure 1

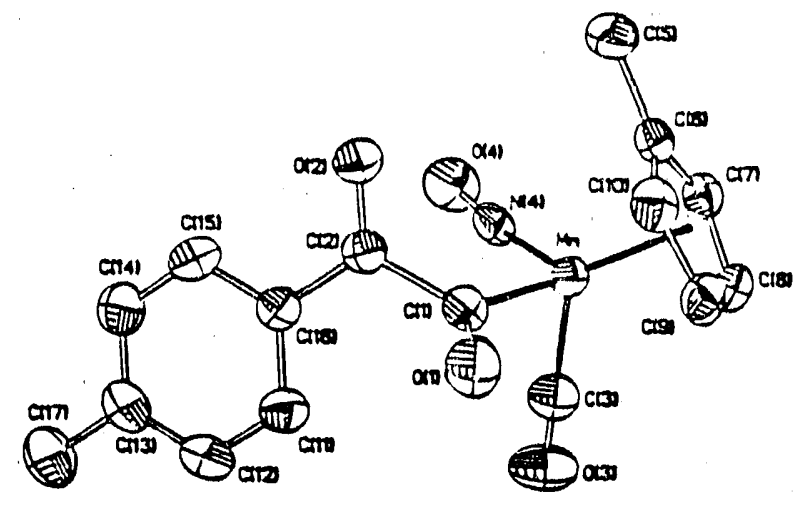

$\left[\mathrm{Cp}(\mathrm{CO})_{2} \mathrm{Mn}-\mathrm{C}(\mathrm{O}\} \mathrm{Tol}\right]^{-}, \underline{\mathbf{5}}$, with $\left[\mathrm{Cp}_{2} \mathrm{Fe}\right]^{+}$, eq. 2. IR monitoring showed that complex $\underline{4}$

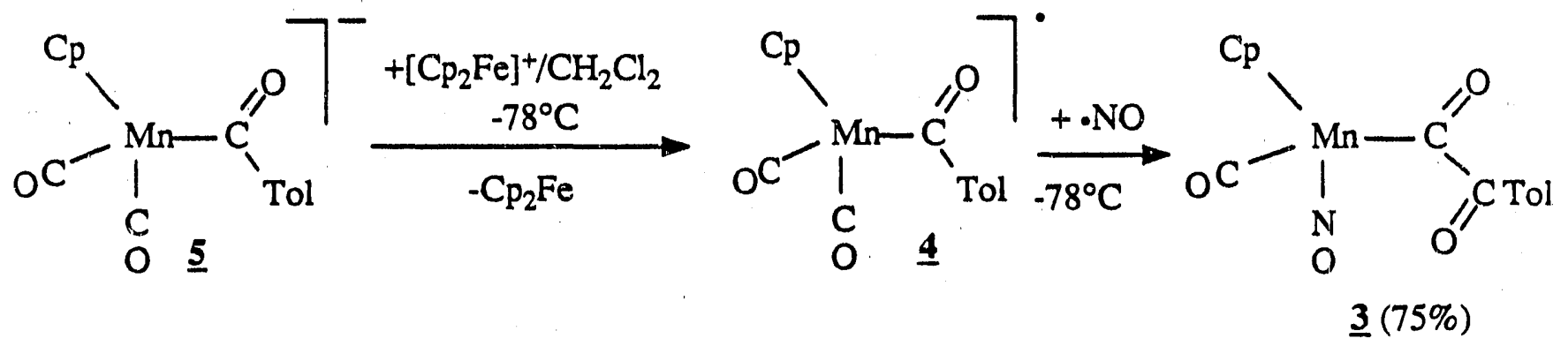

survives warmup to room temperature, although it slowly decomposes to $\mathrm{CpMn}(\mathrm{CO})_{3}$ and other unidentified products over several hours at $22^{\circ} \mathrm{C}$. Significantly, treatment of $-78^{\circ} \mathrm{C}$ solutions of $\underline{4}$ with bubbling NO gas led immediately to formation of the $\alpha$-ketoacyl complex, 3 , eq. 2 . This reaction was quantitative by $I R$, and complex $\underline{3}$ was isolated in $75 \%$ recrystallized yield. ${ }^{3}$ Note that the overall conversion of $\underline{\mathbf{5}}$ into $\underline{\mathbf{3}}$ occurs by the migratory-insertion of $\mathrm{CO}$ into the metal-acyl bond of $\underline{\mathbf{5}}$.

The comprehensive mechanism proposed to account for both reactions 1 and 2 is shown in Scheme 1. A key intermediate which connects these reactions is the $17 \mathrm{e}^{-}$acyl complex $\underline{4}$. This species is proposed to form from the carbene complex $\underline{2}$ by cleavage of the oxygen-nitrogen bond, releasing NO in the process. Alternatively, $\underline{4}$ can be generated by oxidation of the $18 \mathrm{e}^{-}$acyl complex 5 . The $\alpha$-ketoacyl complex $\underline{3}$ then forms via addition of NO to $\underline{4}$. Nitric oxide clearly plays a pivotal role in the $\underline{4}$ to $\underline{\mathbf{3}}$ conversion, and this process can be rationalized by assuming that the NO radical adds to the $17 \mathrm{e}^{-}$complex $\underline{4}$ to give the $18 \mathrm{e}^{-}$irtermediate $\underline{6}$, having a bent, $1 e^{-}$ donor NO ligand, Scheme 2. However, the more common bonding mode of a nitrosyl ligand in low-valent organometallic complexes is as a linear $3 \mathrm{e}^{-}$donor. In order to achieve this bonding form in a stable $18 \mathrm{e}^{-}$product, either a $\mathrm{CO}$ ligand must be lost from $\underline{6}$ or a $\mathrm{CO}$ must insert into the metal-acyl bond. The latter reaction occurs in the above chemistry, with the energy gained in the bent to linear conversion of the NO ligand apparently providing the driving force for the acyl to CO migration. 


\section{$\underline{\text { Scheme } 1}$}

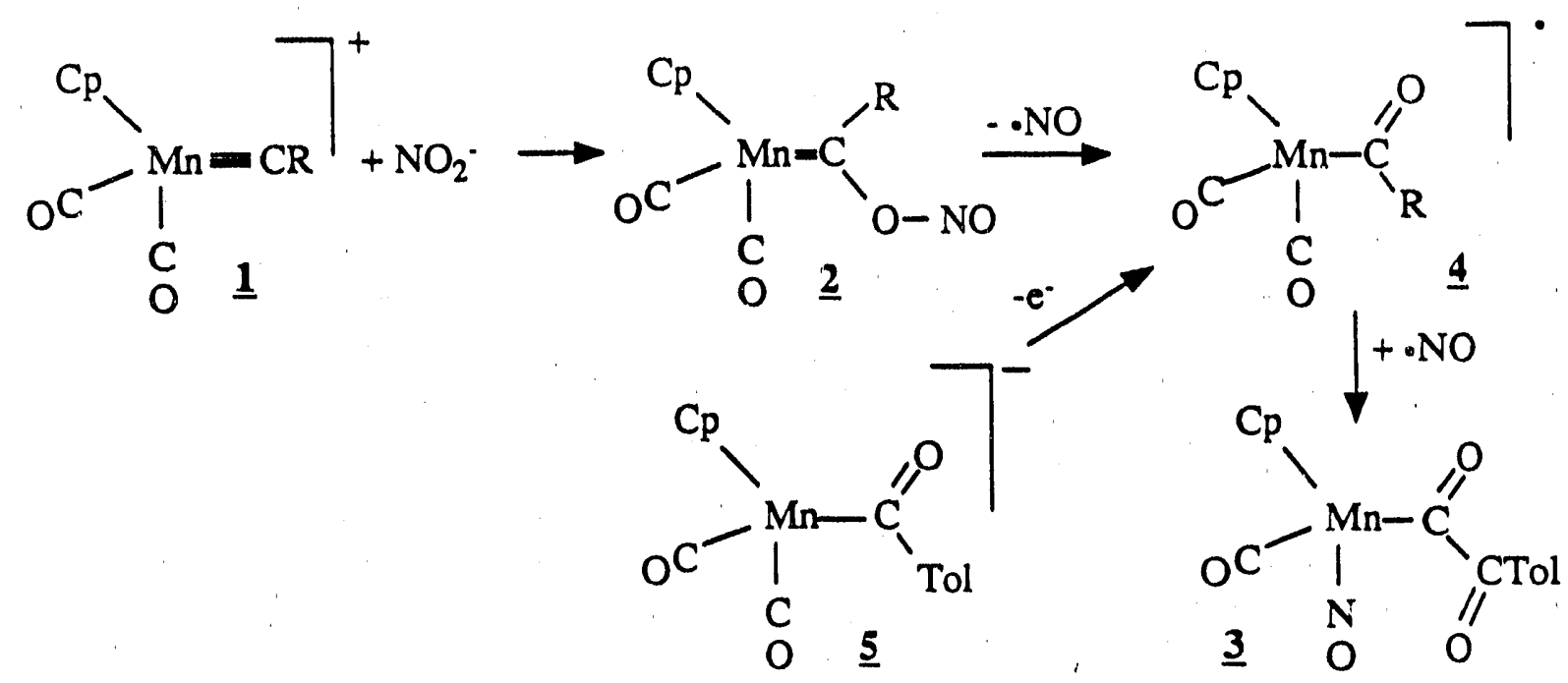

\section{Scheme $\underline{2}$}

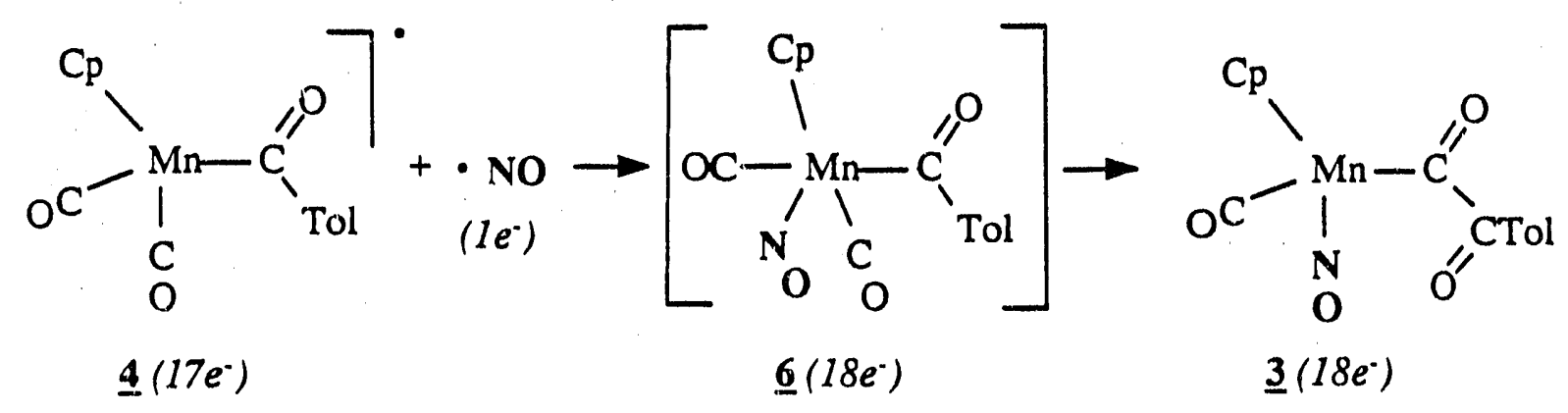

The migratory-insertion of $\mathrm{CO}$ into the metal-acyl bond is not confined to manganese nor to anionic acyl complexes since the neutral iron acyl complex $\mathrm{Cp}(\mathrm{CO})\left(\mathrm{PPh}_{3}\right) \mathrm{Fe}-\mathrm{C}\{\mathrm{O}\} \mathrm{Me}$ undergoes a similar transformation to give the corresponding cationic $\alpha$-ketoacyl complex $\underline{7}$, eq. $3 .{ }^{2}$ Likewise, insertion of $\mathrm{CO}$ into the iron-methyl bond of $\mathrm{Cp}(\mathrm{CO})\left(\mathrm{PPh}_{3}\right) \mathrm{Fe}$-Me has been found to be promoted by a similar oxidation/NO addition reaction sequence, eq. 4. Complex $\underline{8}$ is an unusual example of a cationic acyl complex. The iron center is chiral and the complex is isoelectronic with the neutral chiral acyl complex $\mathrm{Cp}(\mathrm{CO})\left(\mathrm{PPh}_{3}\right) \mathrm{Fe}-\mathrm{C}\{\mathrm{O}\}$ Me which has been shown to be a useful reagent for stereospecific syntheses of organic compounds. ${ }^{5}$ Compound $\underline{\mathbf{8}}$, as well as $\underline{\mathbf{7}}$, may find similar applications, but modified by the cationic character of the complex.

The most important aspect of the work described above is the demonstration that $\alpha$-ketoacyl ligands can be formed by the migratory-insertion of $\mathrm{CO}$ into metal-acyl bonds. Although it was 


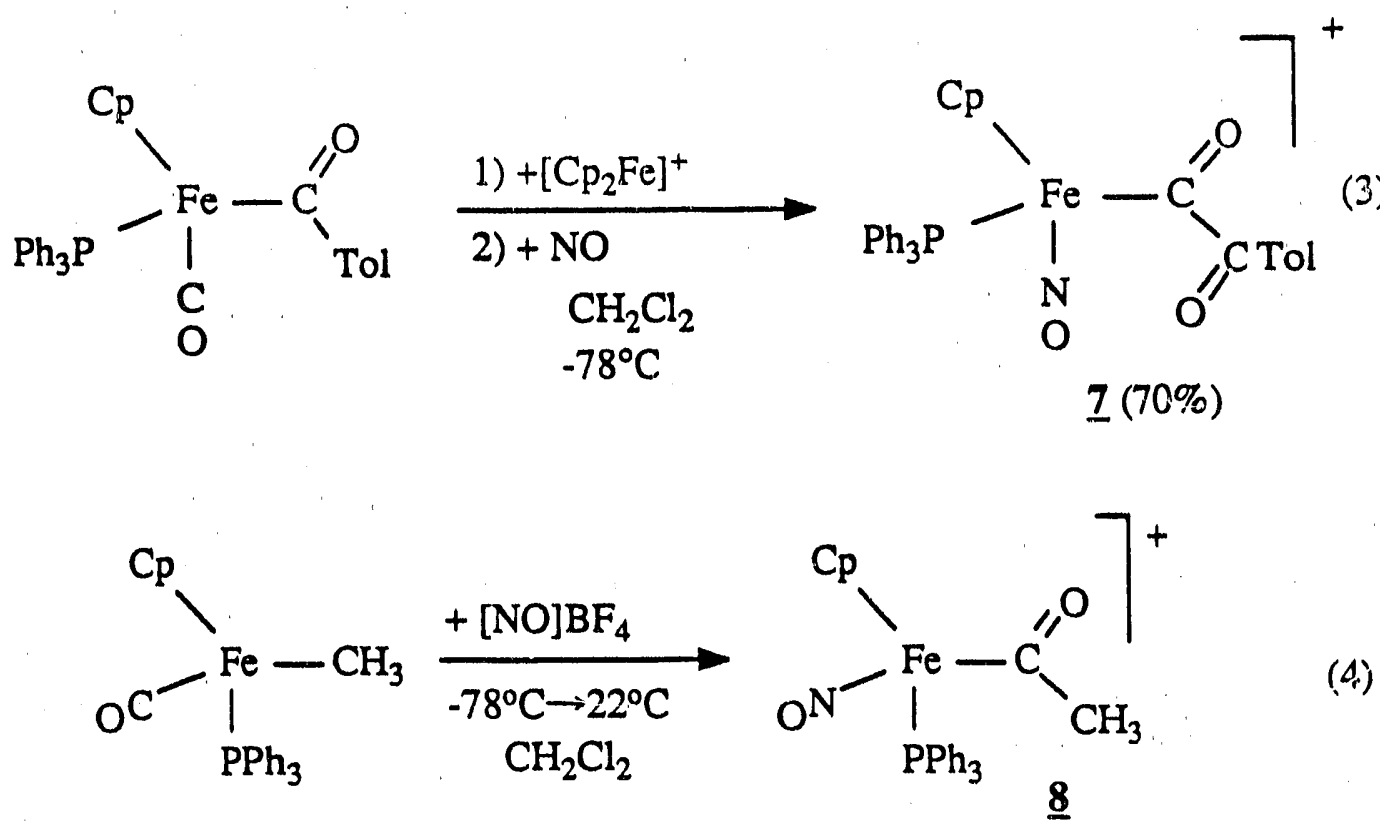

necessary to use the unusual oxidation/NO addition reaction sequence to accomplish this transformation, the results described herein clearly show that this is a viable reaction step and one that must be considered in discussions of "double carbonylation" reactions.

II. Reactivity of the $\alpha$-Ketoacyl Ligand in $\mathrm{Cp}(\mathrm{L})(\mathrm{NO}) \mathrm{Mn}-\mathrm{C}\{\mathrm{O}\} \mathrm{C}\{\mathrm{O}\}$ 'Tol. After preparing the above-described $\alpha$-ketoacyl complexes, we recognized that relatively little was known about the chemical properties of $\alpha$-ketoacyl ligands. We thus undertook an exploration of the reactivity of $\alpha$-ketoacyl complex $\underline{3}^{6.7}$ The first observation was that when heated in toluene $\left(66^{\circ}, 12 \mathrm{~h}\right)$ in the presence of $\sim 1$ equivalent of $\mathrm{PPh}_{3}$, complex $\underline{3}$ gave the phosphine substituted complex $\underline{9}$. This species was more conveniently prepared by photolyzing $\underline{3}$ with excess $\mathrm{PPh}_{3}$, eq. 5 . The $\mathrm{Bu} \mathrm{u}^{\mathrm{t}} \mathrm{N} \equiv \mathrm{C}$

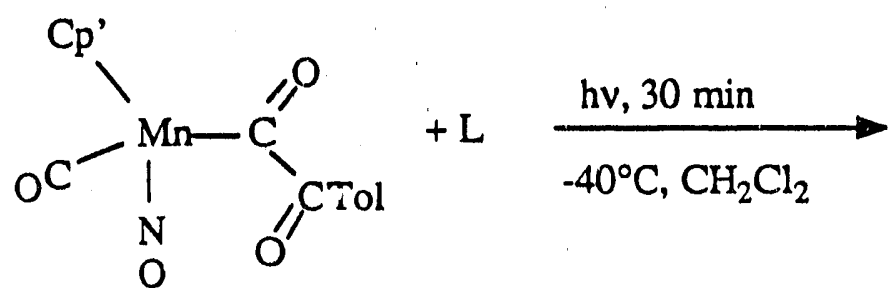<smiles>[Y][Y14]([H])(N=O)C(=O)C(=O)[GeH2]</smiles>

$\underline{3}$

9, $\mathrm{L}=\mathrm{PPh}_{3}, 84 \%$

$\underline{10}, \mathrm{~L}=\mathrm{Bu} \mathrm{u}^{\mathrm{N}} \mathrm{N} \equiv \mathrm{C}, 67 \%$

substituted derivative $\underline{10}$ was similarly prepared. A surprising feature of the chemistry of the $\alpha$-ketoacyl complex $\underline{3}$ is its resistance to CO deinsertion to form an acyl complex when either heated or irradiated in the absence of added ligand. ${ }^{3 a}$ Under these conditions, orly slow decomposition occurred as evidenced by the gradual disuppearance of all IR bands in the 
$1600-2000 \mathrm{~cm}^{-1}$ region. To explore the basis for this surprising result, we recently completed a low-temperature photochemical study of the complex with the assistance of Derk Stufkens of the University of Amsterdam. ${ }^{8}$ IR monitoring showed that irradiation at $-140^{\circ} \mathrm{C}$ in $2-\mathrm{MeTHF}$ and at $-100^{\circ} \mathrm{C}$ in $\mathrm{CH}_{2} \mathrm{Cl}_{2}$ gave spectral changes consistent with formation of the 11-cis and 11-trans products shown in Scheme 3 which derive from photoinduced CO loss from the S-cis and S-trans isomers of $\mathbf{3}$. Paticularly indicative of this proposal is the loss of the nietal carbonyl stretch, the

\section{Scheme 3}
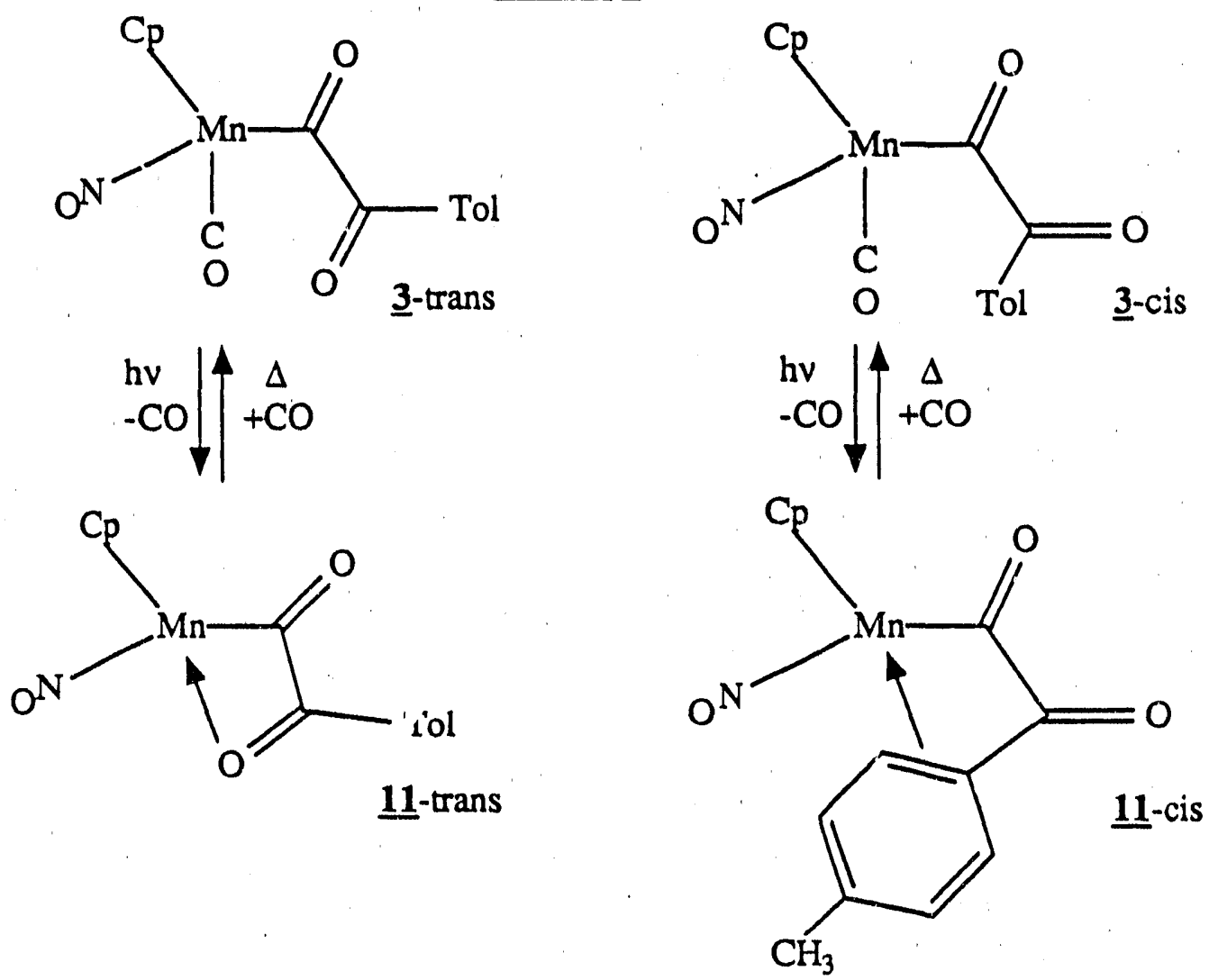

appearance of the $v_{C O}$ band of free $\mathrm{CO}$, and the $50 \mathrm{~cm}^{-1}$ shift of the IR band assigned to the $\beta$-carbonyl of the $S$-trans isomer upon photolysis as compared to the smaller $15 \mathrm{~cm}^{-1}$ shift of the analogous band of the S-cis isomer.

An intriguing reaction occurred when the $\mathrm{PPh}_{3}$ substituted $\alpha$-1. atoacyl complex was protonated. When this species was treated with one equiv of $\mathrm{HBF}_{4} \cdot \mathrm{Et}_{2} \mathrm{O}$ at room temperature, the known complex $\left[\mathrm{Cp}^{\prime} \mathrm{Mn}(\mathrm{CO})(\mathrm{NO})\left(\mathrm{PPh}_{3}\right)\right]^{+}, \underline{12},{ }^{9}$ and 4-methylbenzaldehyde rapidly formed, eq. 6. ${ }^{6}$ As indicated in the equation, a ${ }^{13} \mathrm{C}$ labeling study using 9 exclusively enriched in ${ }^{13} \mathrm{C}$ at the $\alpha$-carbonyl carbon led to $\underline{12}$ with a ${ }^{13} \mathrm{C}$ enriched $\mathrm{CO}$ ligand. This demonstrates that the metal coordinated $\mathrm{CO}$ in $\underline{\mathbf{1 2}}$ derives from the $\alpha$-carbonyl of the $\alpha$-ketoacyl ligand, and thus protonation induces cleavage of the $\alpha$-ketoacyl carbon-carbon bond. When reaction 6 was conducted at $-78^{\circ} \mathrm{C}$ and monitored by $I R$, an intermediate $(13)$ formed $\left(v_{\mathrm{NO}}=1771 \mathrm{~cm}^{-1}\right)$ which then gave $\underline{12}$ upon 


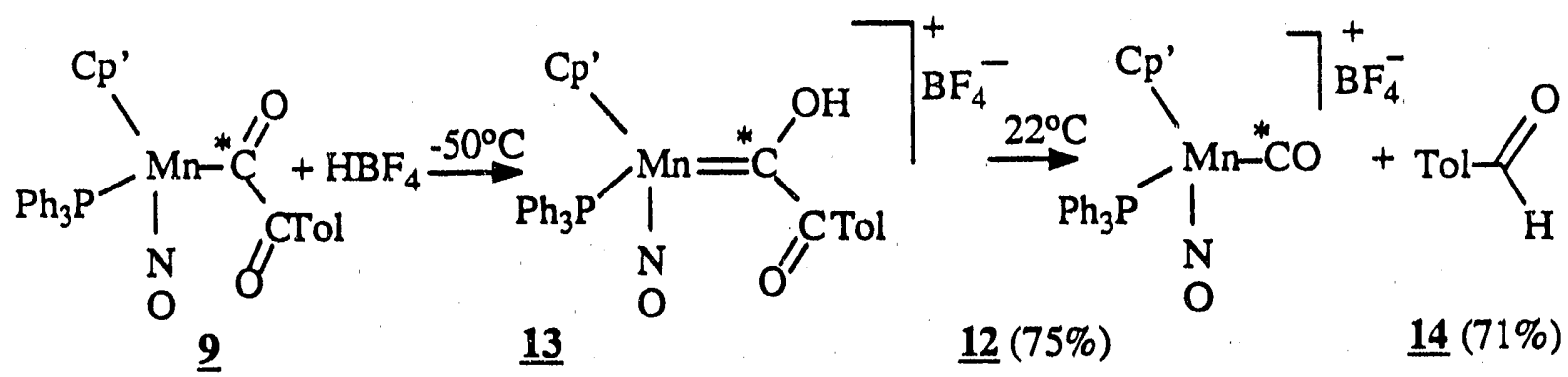

warmup. Similar ${ }^{13} \mathrm{C}$ NMR monitoring of the $-50^{\circ} \mathrm{C}$ protonation of 9 , enriched at the $\alpha$-carbon of the $\alpha$-ketoacyl ligand, showed a resonance at $\delta 335.4\left(\mathrm{~d}, \mathrm{~J}_{\mathrm{C} . \mathrm{P}}=23 \mathrm{~Hz}\right.$ ) due to the intermediate species. Upon warming to $0^{\circ} \mathrm{C}$, the $\delta 335.4$ resonance decreased in intensity as the $\delta 223.6$ resonance of $\underline{12}$ grew in. These intermediate spectroscopic features are attributed to the hydroxycarbene complex $\underline{13}$ illustrated in eq. 6 . This is the logical product of protonation since many acyl complexes have been shown to undergo protonation at the acyl carbonyl oxygen to give hydroxycarbene derivatives. ${ }^{10}$ The most likely mechanism for the $\underline{13} \rightarrow \underline{12}+\underline{14}$ conversion is one involving an intramolecular hydrogen shift concomitant with cleavage of the carbon-carbon bond in the $\alpha$-ketoacyl ligand, as outlined in eq. 7.

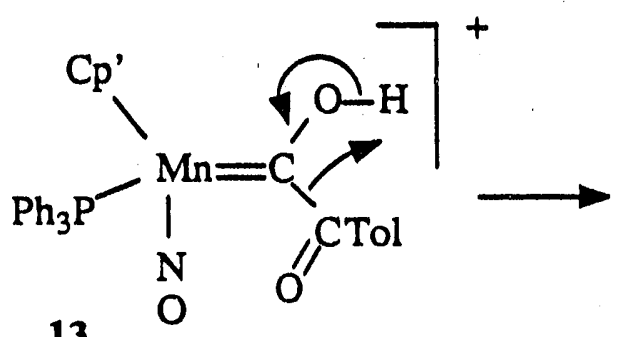

13

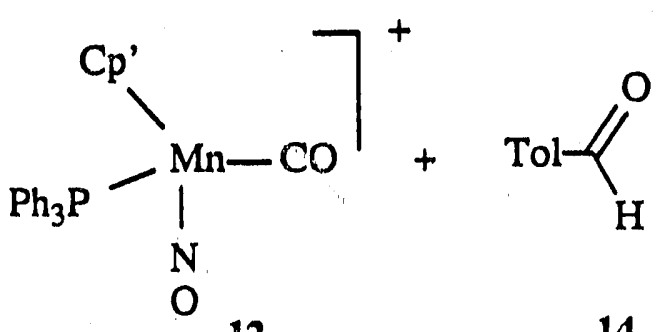

12

Cleavage of the $\alpha$-ketoacyl carbon-carbon bond also occurred when complex $\underline{9}$ was oxidized. Treatment of a $\mathrm{CH}_{2} \mathrm{Cl}_{2}$ solution of $\underline{9}$ at $-78^{\circ} \mathrm{C}$ with one equivalent of $\left[\mathrm{Cp}_{2} \mathrm{Fe}\right]^{+}$or $\mathrm{Ag}^{+}$ resulted in near instantaneous and quantitative conversion to the known cation $\underline{12}$, along with a complex mixture of organic products, eq. 8 . The only organic formed in substantial yield and the

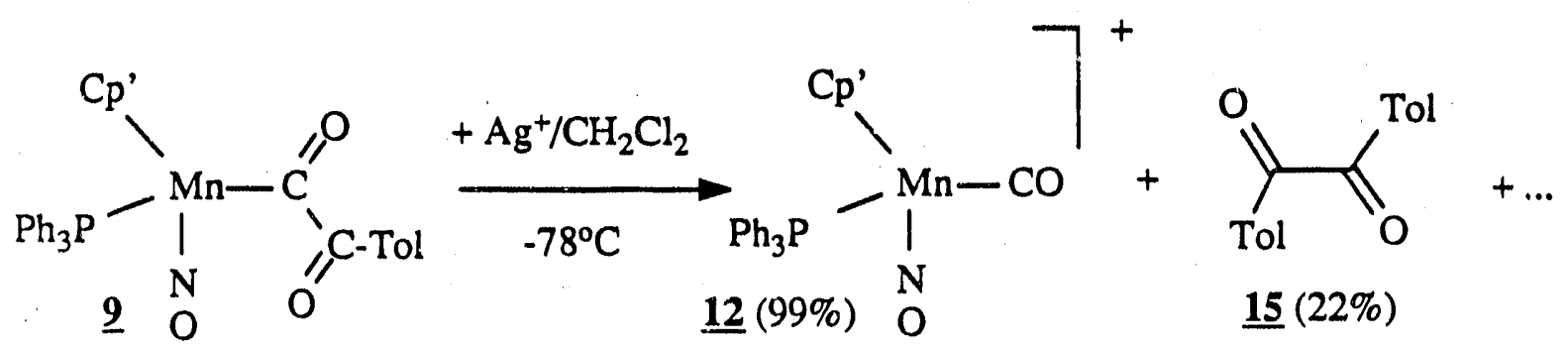

only one confidently identified was TolC $(O\}-\mathrm{C}\{\mathrm{O}\} \mathrm{Tol}, \underline{15}$. The stoichiometry of this reaction indicates that oxidation induces cleavage of the carbon-carbon bond of the $\alpha$-ketoacyl ligand to form 12 and Tol-C $\{\mathrm{O}\}$ - radicals. A substantial fraction of the latter must couple to form the observed 15 , with the remainder decaying to other unidentified organic products.

To explore the possiblility of coordination and then interaction of small organic molecuies with the $\alpha$-ketoacyl ligand in complex $\underline{\mathbf{3}}$, this species was irradiated in the presence of alkynes in 
anticipation of photosubstitution of alkyne for CO. Rapid reaction occured with small electron-rich alkynes to form metallacycles of the type 17 depicted in eq. 9 for $\mathrm{MeC} \equiv C M e .^{6}$ The

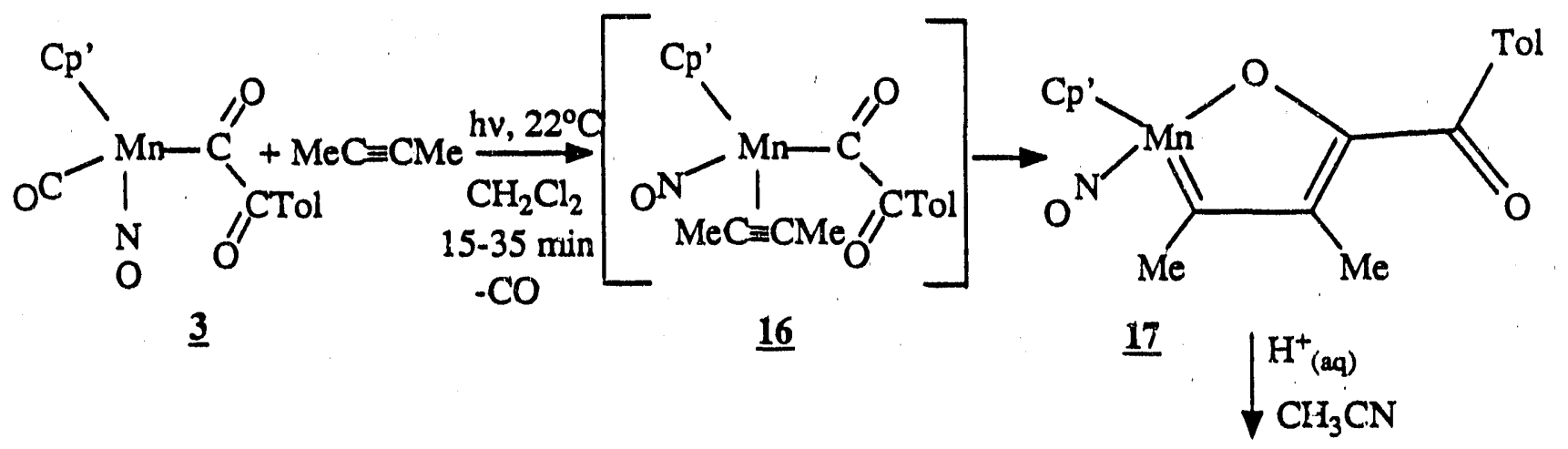<smiles>CC=C(C)C(=O)C(=O)Cl</smiles>

intermediate alkyne complex $\underline{16}$ was not detected, but it is the logical species that would result upon photoinduced $\mathrm{CO}$ loss and coordination of alkyne. Similar metallacycles were observed to form upon reaction of $\underline{\mathbf{3}}$ with $\mathrm{Bu}^{\mathrm{t}} \mathrm{C} \equiv \mathrm{CH}, \mathrm{MeC} \equiv \mathrm{CEt}$, and $\mathrm{MeC} \equiv \mathrm{CPh}$ under photochemical conditions. The metallacycle produced in the above reaction is extremely susceptible to hydrolysis, and the complex can easily be demetallated by addition of aqueous $\mathrm{HCl}$ to a $\mathrm{CH}_{3} \mathrm{CN}$ solution of the complex and also to a large extent upon chromatographic work-up, to form the vinyl $\alpha$-dione $\underline{18}$, eq. 9.

III. New Transformations of Binuclear Iron Carbonyl Complexes. In the course of our studies of ketene ligands, we sought ways to transform these ligands into other types of organics. Particularly interesting was their conversion into ketenimine ligands via deoxygenation with phosphinimines, eq. 10. One such attempt this past year with the potential ketene precursor

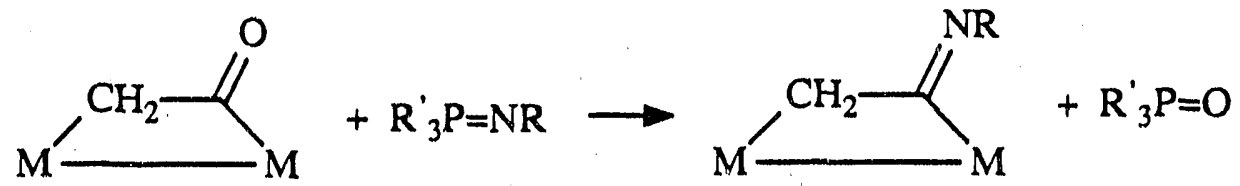

$\mathrm{Fe}_{2}\left(\mu-\mathrm{CH}_{2}\right)(\mathrm{CO})_{8}, \underline{19}$, gave instead a remarkable and unprecedented series of transformations which are summarized in Scheme 4 on the next page. ${ }^{11}$ The initial products isolated from the reactions of $\underline{19}$ with $\mathrm{Bu}_{3} \mathrm{P}=\mathrm{NBu}^{\mathrm{t}}$ and $\mathrm{Ph}_{3}=\mathrm{NPh}$ were the 3-ferra-4-pyrrolin-2-one complexes 20a and $20 \mathrm{~b}$. This type of metallacycle had not been previously reported, although these complexes are isomeric with several known ferra-pyrrolinones in which the carbonyl and imido groups have 


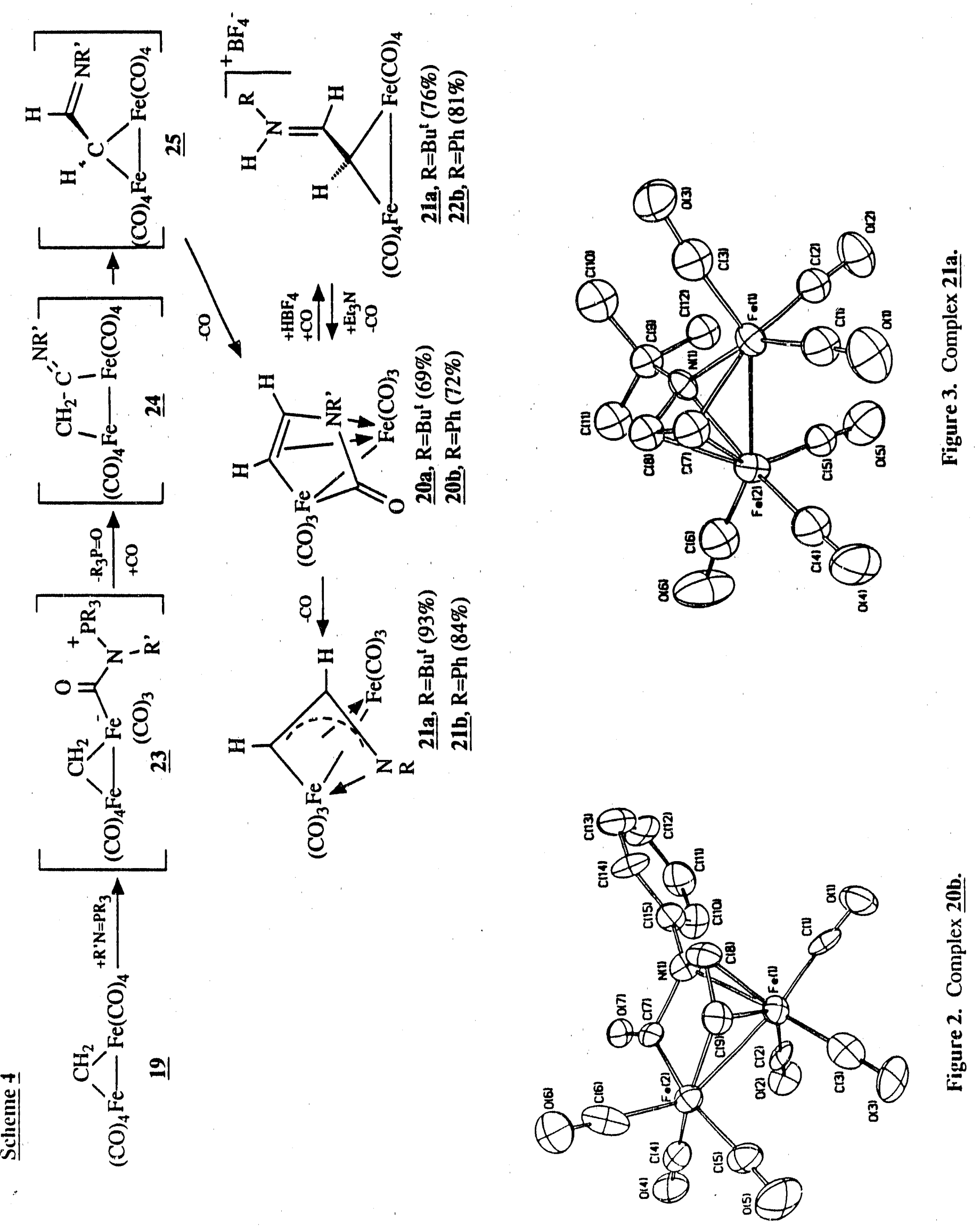


exchanged positions. ${ }^{12}$ However, unlike those isnmers, complexes $\underline{20 a, b}$ slowly de-insert $\mathrm{CO}$ to form the 2-ferra-3-azetine complexes 22a,b which are also new types of metallacycles. In addition to spectroscopic characterization, the new complexes $\underline{20 \mathrm{~b}}$ and $\underline{21 \mathrm{a}}$ have been crystallographically defined, Figures 2 and 3 .

The likely mechanism by which the ferra-pyrrolinone complexes $\underline{20 \mathrm{a}, \mathrm{b}}$ derive from $\underline{19}$ is shown in Scheme 4. Evidence for initial addition of the phosphinimine to a carbonyl carbon to form 23 comes from the observation that the $\mu-\mathrm{CMe}_{2}$ analog of $\underline{19}$ reacts with $\mathrm{Bu} \mathrm{N}=\mathrm{P}(\mathrm{Bu})_{3}$ to form a similar complex which has been isolated and spectroscopically characterized $\left[v_{C O}=1752\right.$ $\mathrm{cm}^{-1} ;{ }^{13} \mathrm{C}$ NMR: $\left.\delta 231.7\left(C[\mathrm{O}) \mathrm{NBu}^{2}\right)\right]$. Phosphinimines have been previously proposed to deoxygenate carbonyl ligands via this type of intermediate, and species like this form from the reactions of ylides with metal carbonyls. ${ }^{13}$ Elimination of $R_{3} P=O$ from $\underline{23}$ would form the ketenimine complex $\underline{24}$ which must then rearrange to the formimido carbene complex $\underline{25}$, similar to rearrangements previously observed by Pettit in related compounde. ${ }^{14}$ Nucleophilic attack of the imine nitrogen of $\underline{25}$ on a $\mathrm{CO}$ ligand would yield the ferra-pymolinone ring. Evidence for this step comes from observation that treatment of the protonated azaallylidene complexes $22 \mathrm{a}, \mathbf{b}$ (Scheme 4) with base leads to quantitative formation of the ferra-pyrrolinone complexes $20 \mathrm{a}, \mathrm{b}$, presumably by attack of the imine nitrogen on a $\mathrm{CO}$ ligand concomitant with $\mathrm{CO}$ loss from the metal framework. The $\underline{23}$ to $\underline{24}$ conversion does not likely proceed via decay of $\underline{23}$ into $\mathrm{O}=\mathrm{PR}_{3}$ and a $C \equiv N R$ ligand which could insert into the metal carbene bond to form 24, since reaction of $\underline{19}$ with $\mathrm{Bu}^{\mathrm{t}} \mathrm{N} \equiv \mathrm{C}$ does not yieid any of the products described above.

As illustrated in Scheme 5, the ferra-azetine complexes 21a,b have also been found to undergo reversible carbonylation to give isomeric ferra-pyrrolinone complexes, depending upon whether thermal or photochemical conditions are used. Under photochemical conditions in the presence of $1 \mathrm{~atm} \mathrm{CO}$, the 3-ferra-4-pyrrolin-2-one complexes 20a and 20b were formed in near quantitative yield. However, when complexes 21a,b were stirred at room temperature under 1 atm $\mathrm{CO}$, carbonylation occurred at the other end of the metallacycle to give the 2-ferra-4-pyrrolin-3-one complexes $\underline{26 \mathrm{a}}$ and $\underline{\mathbf{2 6}}$ b, which are also completely new types of metallacycles, but with no trace of $\underline{20 a}$ or $\underline{20} \underline{b}$. For complex $\underline{21 b}$, this latter reaction was rapid (1h), and 26b was isolated in $72 \%$ yield by slow evaporation of solvent under a CO atm. However, with complex 21a, ${ }^{1} \mathrm{H}$ NMR analysis showed formation of an equilibrium mixture of 26a (18\%) and 21a (82\%), and we were unable to isolate 26a because of its facile conversion back to 21a when the $\mathrm{CO}$ atm was removed. Similarly, complex $\underline{26 \mathrm{~b}}$ reformed $\underline{21 \mathrm{~b}}$ when solutions were stirred under an $\mathrm{N}_{2}$ atm.

In the course of the studies described in the above sections, we discovered a metal-assisted route to mono-, di-, and tri-substituted 2-pyridinones based on the reaction of phosphininines 


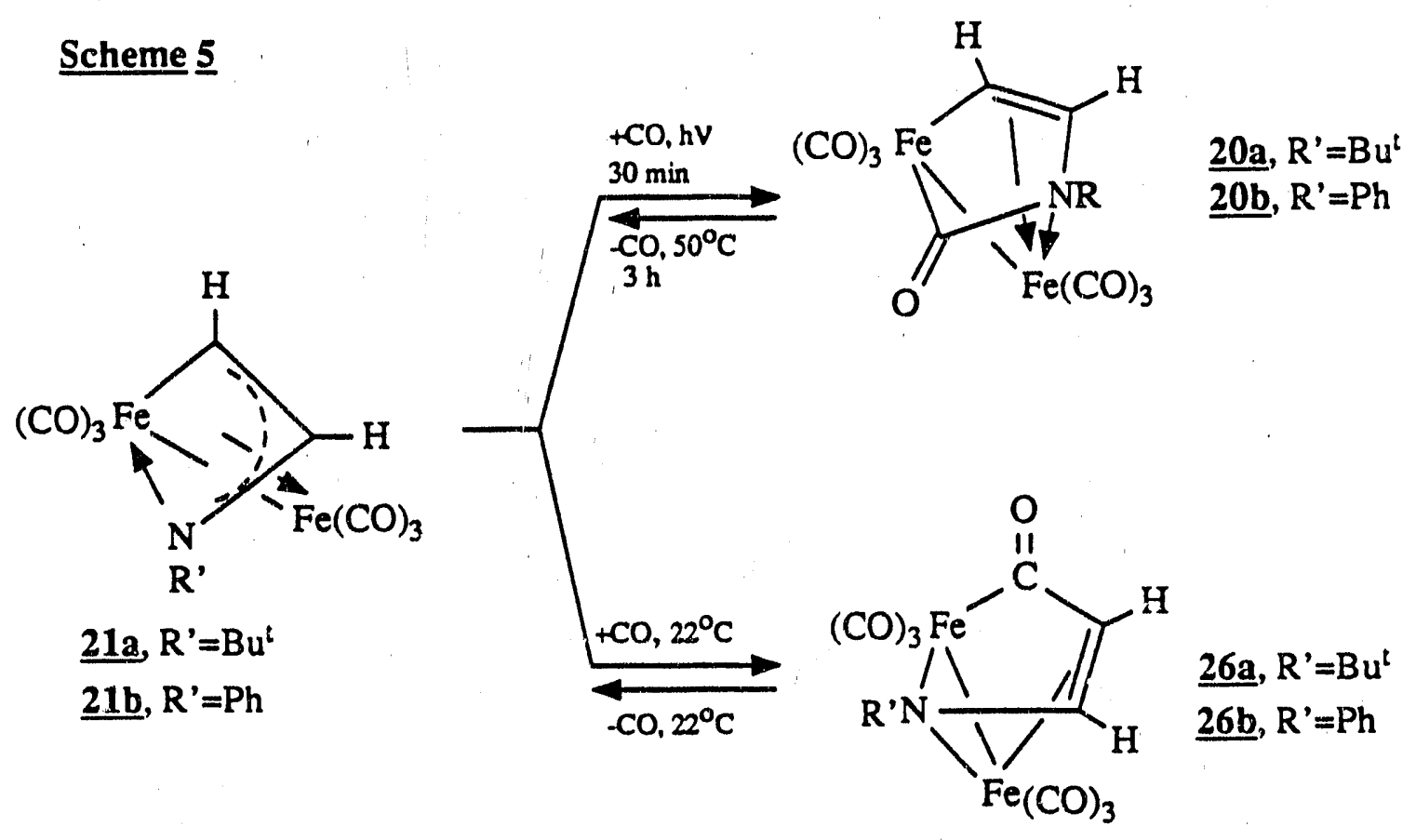

with $\mathrm{Fe}_{2}\left(\mu-\mathrm{CH}_{2}\right)(\mathrm{CO})_{8}$. The binuclear ferra-azetine complex $\underline{21 a, b}$ were found to readily insert alkynes into the Fe-carbon bond under photochemical conditions to give the ferra-pyridine complexes 27a-g shown in Scheme $6{ }^{15}$ These latter species were isolated in $72-87 \%$ yields as microcrystalline solids and have been spectroscopically characterized, with complex $27 \mathrm{e}$ $\left(\mathrm{R}^{1}, \mathrm{R}^{2}, \mathrm{R}^{3}=\mathrm{Ph}\right)$ fully defined by an $\mathrm{X}$-ray diffraction study, Figure 4. NMR data indicate that terminal alkynes insert regiospecifically to give only the isomer with the substituted carbon adjacent to the iron center. ${ }^{15}$ As illustrated in Scheme 6, free 2-pyridinones were readily released when complex $\underline{27}$ was either heated under $600 \mathrm{psi} \mathrm{CO}$ in the presence of 1 eq of [PPN]Cl or when refluxed in $\mathrm{CH}_{3} \mathrm{CN}$ solution. The 2-pyridinones $28 \mathrm{a}$-g were isolated by silica gel chromatography and were spectroscopically characterized. The overall reaction occurs with high regiospecificity due to the selectivity of the alkyne insertion step to form the ferra-pyridines. In the case of mono-substituted alkynes, the substituted carbon atom is always adjacent to the iron center in the ferra-pyridine ring and hence adjacent to the nitrogen atom in the pyridinone.

As shown in Table I, this synthetic method allows for strong substituent control at the 1and 3-positions by varying the phosphinimine and the alkynes employed. Significantly, the $\mathrm{Bu}^{\mathrm{t}}-\mathrm{N}$ substituted 2-pyridinones can be converted into $\mathrm{N}-\mathrm{H}$ 2-pyridinones by refluxing in $\mathrm{CF}_{3} \mathrm{CO}_{2} \mathrm{H}$ followed by $\mathrm{K}_{2} \mathrm{CO}_{3}$ (aq) workup as illustrated by entries $\underline{\mathbf{2 8 \mathrm { h }}}$ and $\underline{\mathbf{2 8 \mathrm { i }}}$ in Table I. The $\mathrm{N}-\mathrm{H}$ pyridinones are an important class of biologically active molecules, with $\underline{28 \mathrm{i}}$ being a patented anti-inflammator; agent. Further, $\mathrm{N}-\mathrm{H}$ 2-pyridinones give wide potential substituent variability at this position by employing many of the known methods for alkyl and aryl substitution. Entry $\mathbf{2 8 g}$ is particularly attractive since it not only demotistrates the versatility in choice of alkyne, but also 

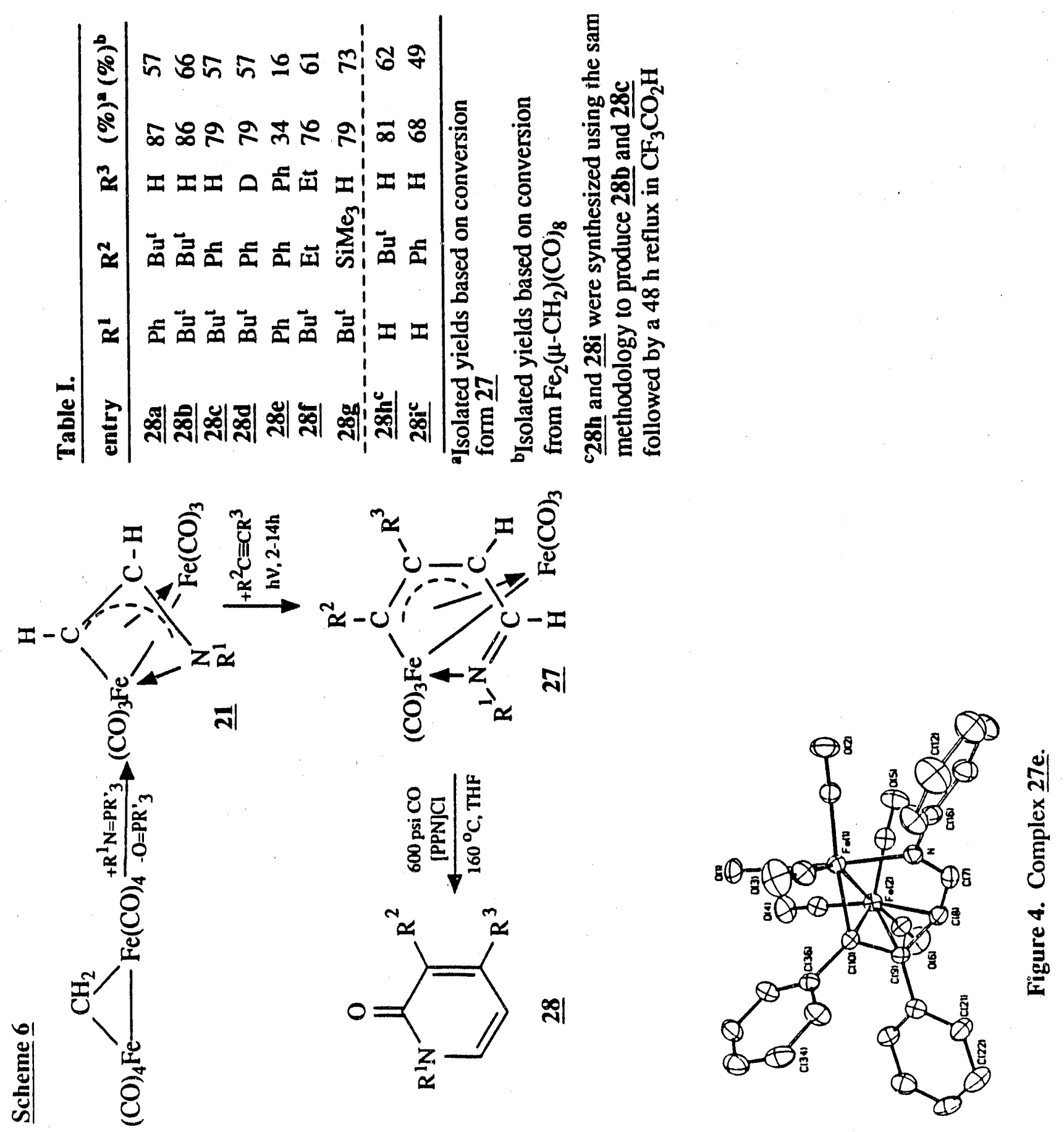
the added $\mathrm{SiMe}_{3}$ functionality allows for further manipulation at the 3-position by known organic methods.

This synthetic route for pyridinones off $t ; s$ a convenient step-wise synchesis of cubstituted pyridinones from readily available starting materials -- alkynes, phosphinimines, and $\mathrm{Fe}_{2}\left(\mu-\mathrm{CH}_{2}\right)(\mathrm{CO})_{8}$. It also has many advantages over conventional methods of pyridinone synthesis. First of all, it employs simple, inexpensive, and readily available starting materials. Secondly, it appears to have wide substituent variability, both on the nitrogen atom and the alkyne. Finally, the starting complex $\mathrm{Fe}_{2}\left(\mu-\mathrm{CH}_{2}\right)(\mathrm{CO})_{8}$ and the inter.dediate metallacycles are not particularly air-sensitive, and the reactions can be readily conducted under tank $\mathrm{N}_{2}$. Its limitation is that presently only tri-substituted pyridinones can be formed as the substituents in the 5 and 6 positions of the pyridinone ring are limited to hydrogen atoms. Current efforts are aimed at developing methodology to synthesize 5-substituted pyridinones as well as the 4-substituted isomer not observed in this reaction.

IV. Halide-Promoted Insertion of Carbon Monoxide into Iron- $\mu$-Carbene Bonds. A long-standing research theme in our DOE supported research has involved studies of the halide-promoted insertion of carbon monoxide into metal-carbene and metal-nitrene bonds. We recently investigated the reactivity of halides with methylene complex $\mathrm{Fe}_{2}(\mathrm{CO})_{8}\left(\mu-\mathrm{CH}_{2}\right)$ which has been shown by Keim to require extreme conditions ( $40 \mathrm{~atm} ; 70^{\circ} \mathrm{C}, 24 \mathrm{~h}$ ) for carbonylation to occur in the absence of a nucleophile. ${ }^{16}$ Keim also showed that in the presence of methoxide ion, carbonylation readily occurred under $1 \mathrm{~atm} \mathrm{CO}$ to form methylacetate, but in the absence of methoxide the complex did not react with methanol at room temperature under $1 \mathrm{~atm} \mathrm{CO}$.

We have found that halides and cyanide dramatically piomote the carbonylation of $\mathrm{Fe}_{2}(\mathrm{CO})_{8}\left(\mu-\mathrm{CH}_{2}\right)$ in $\mathrm{CH}_{2} \mathrm{Cl}_{2}$ solution containing a few equivalents of methanol (1 atm $\mathrm{CO} ; 22 \mathrm{C}$; minutes) to form near quantitative yields of methylacetate, but without the detection of organometallic intermediates, eq. 11. The halides $\mathrm{Cl}^{-}, \mathrm{Br}^{-}$, and $\mathrm{I}^{-}$and cyanide are all effective in

$$
\mathrm{Fe}_{2}\left(\mu-\mathrm{CH}_{2}\right)(\mathrm{CO})_{8}+\mathrm{CO}+\mathrm{MeOH} \frac{22^{\circ} \mathrm{C}}{\mathrm{CH}_{2} \mathrm{Cl}_{2}} \mathrm{CH}_{3} \mathrm{C}\{\mathrm{O}\} \mathrm{OMe}
$$

[PPN]X

inducing this transformation, bur in the absence of halide no reaction occurs. The key question concerns exactly how halides promote this and elated carbonylation reactions. We have gained insight into this process by studying the substituted carbene complex $\mathrm{Fe}_{2}(\mathrm{CO})_{8}\left(\mu-\mathrm{CMe}_{2}\right)$. Spectroscopic data indicate that this latter species reacts with halides to form the halocarbonyl complexes shown in eq. 12. Haloacyl complexes have often been suggested as important 


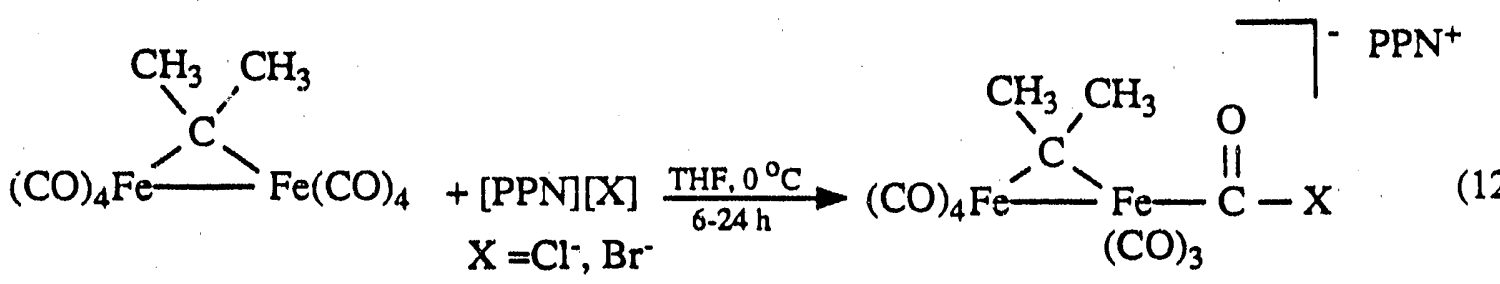

intermediates in a number of halide promoted reactions ${ }^{17}$ but have never been directly observed, except for one serendipitous preparation of the fluoroacyl complex $\left[\mathrm{F}(\mathrm{CO})_{2}\left(\mathrm{PEt}_{3}\right)_{2} \mathrm{Ir}-\mathrm{C}[\mathrm{O}\} \mathrm{F}\right]^{+}$ which was sufficiently stable to isolate and structurally characterize. ${ }^{18}$ The haloacyl complexes shown in eq. 12 are relatively stable compounds and have been isolated and spectroscopically characterized, but they do not further transform into products involving carbonylation of the carbene ligand. Their formation in eq. 12 suggest that halides promote the carbonylation of $\mathrm{Fe}_{2}\left(\mu-\mathrm{CH}_{2}\right)(\mathrm{CO})_{8}$ by a similar process involving initial halide addition to a carbonyl ligand, Scheme 7. Subsequent migration of this ligand to the methylene ligand followed by solvation

\section{Scheme ?}

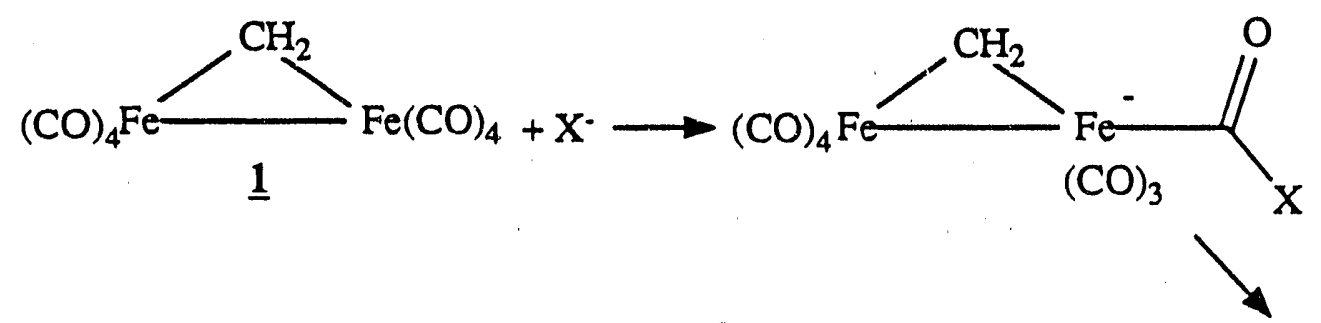

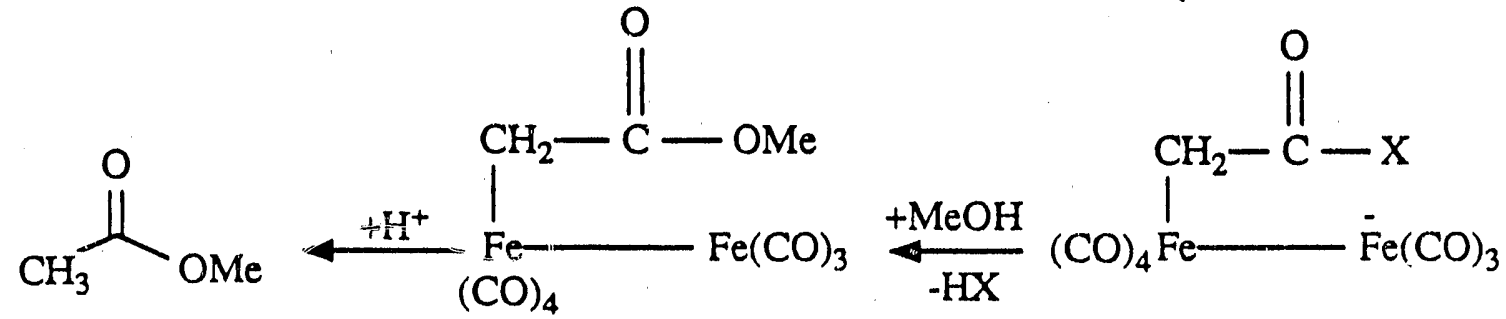

with methanol would give the observed methylacetate product. This proposal, which is in line with the mechanism suggested by Keim for the methoxide induced carbonylation, ${ }^{16}$ relies on the assumption that a haloacyl ligand will rapidly couple with the methylene ligand whereas a $\mathrm{CO}$ ligand does not easily undergo this migration. The function of the halide is then to activate the $\mathrm{CO}$ for the coupling step, and once this step has occurred, the halide is solvated by the methanol solvent.

V. New Addition and Cycloaddition Reactions with Highly Nucleophilic and Chiral Manganese Acetylide Complexes. In an extension of the acyl to $\mathrm{CO}$ migratory-insertion reaction discussed in Section I of this report, we sought to induce a similar migration of a carbene 
ligand by oxidizing the complex $\mathrm{Cp}(\mathrm{CO})_{2} \mathrm{Mn}=\mathrm{C}(\mathrm{OMe}) \mathrm{Me}$. This did not work, but in the course of these studies we prepared and investigated the $\mathrm{PPh}_{3}$ substituted complexes $\mathrm{Cp}(\mathrm{CO})\left(\mathrm{PPh}_{3}\right) \mathrm{Mn}=\mathrm{C}(\mathrm{OMe}) \mathrm{CH}_{2} \mathrm{R}, \underline{29}$, eq. 13. This led to the discovery of a remarkable set of Mn-acetylide and -vinylidene complexes that promise to have considerable potential for use in stereospecific organic and organometallic syntheses. ${ }^{19}$ Complex 29 was found to react with two equivalents of $n$-BuLi to form the anionic acetylide complex $\underline{30}$ shown in eq. $13\left(\mathrm{R}=\mathrm{H}, \mathrm{CH}_{3}, \mathrm{Pr}^{\mathrm{j}}\right)$.

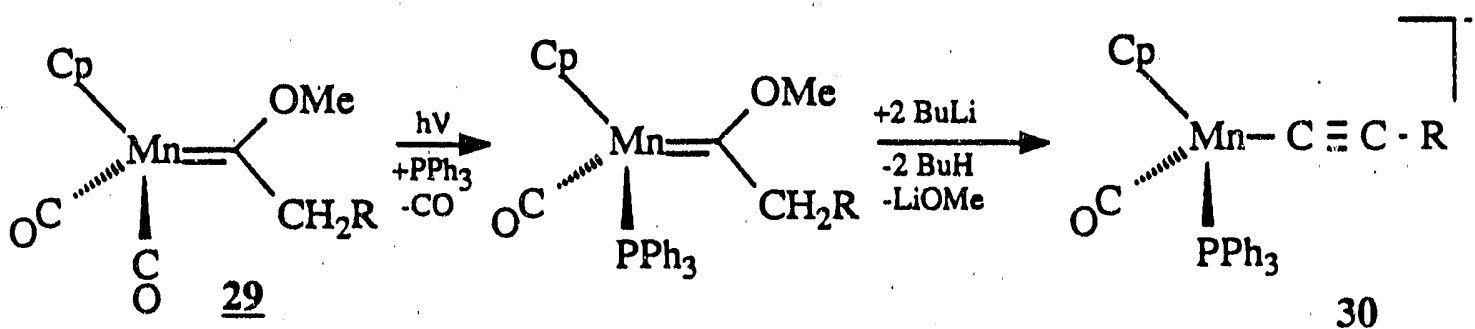

These latter complexes are highly reactive and readily undergo nucleophilic addition to $\mathrm{PhN}=\mathrm{C}=\mathrm{O}, \mathrm{Ph}_{2} \mathrm{C}=\mathrm{C}=\mathrm{O}, \mathrm{CO}_{2}$, vinylketones, and epoxides to give the products illustrated in Scheme 8. All of the products shown in the scheme were isolated as spectroscopically

Scheme $8 \quad[\mathrm{Mn}]^{*}=\mathrm{Cp}^{\prime}(\mathrm{CO})\left(\mathrm{PPh}_{3}\right) \mathrm{Mn}$

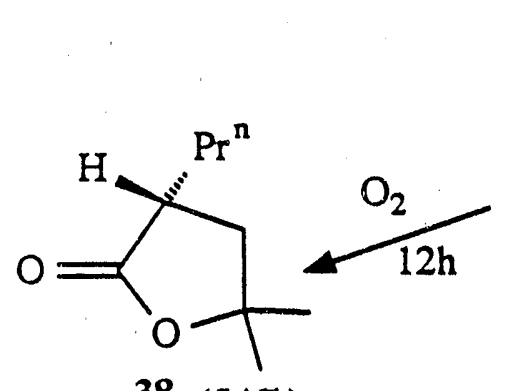

$\underline{38}(54 \%)$
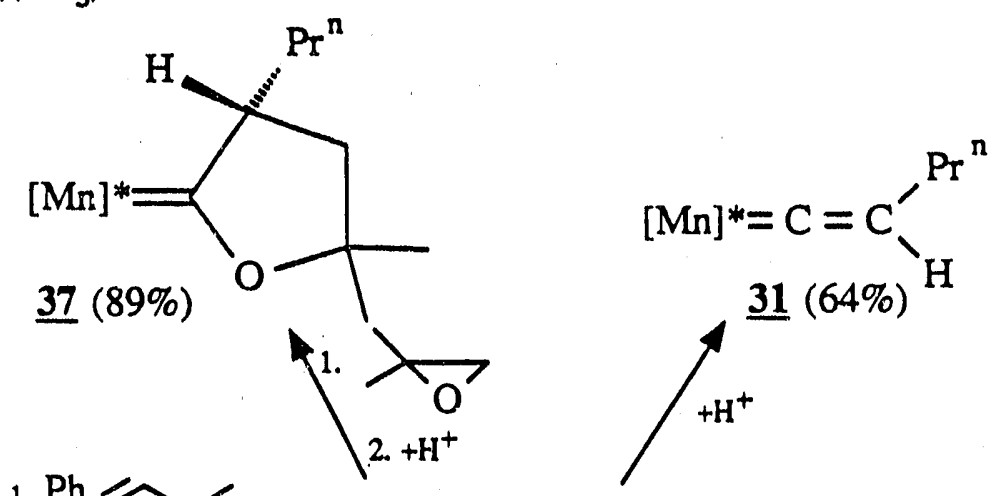

1. $\mathrm{Ph}$<smiles>CCCC(=C=[15N][Na])[C@H](CC(C)=O)c1ccccc1</smiles>

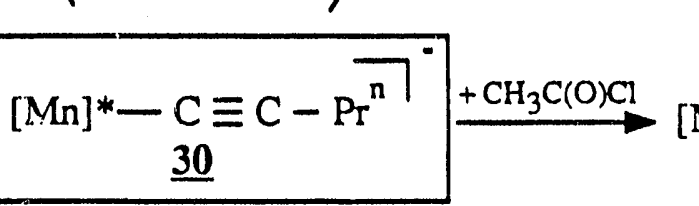<smiles>CCCC(=C=C(C)C)C(C)=O</smiles>

2. $+\mathrm{H}^{+}$

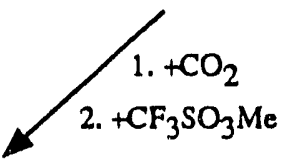<smiles>CCCC(=C=C(C)C)C(=O)OC</smiles>

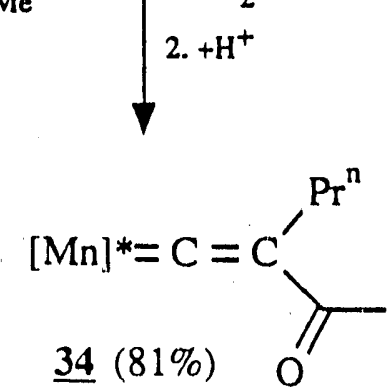

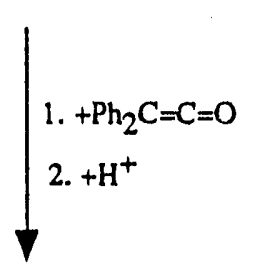

1. + TolN $=\mathrm{C}=0$
$2 .+\mathrm{H}^{+}$<smiles>C=C=C(CCC)C(=O)NCCC</smiles>

$\mathrm{CHPh}_{2}$ 
characterized solids, and complexes $\underline{36}\left(\mathrm{R}=\mathrm{PR}^{\mathrm{n}}\right.$ ) and $\underline{37}$ (with $\mathrm{CH}_{3}$ instead of $\mathrm{Pr}^{\mathrm{n}}$ ) were also characterized by $\mathrm{X}$-ray diffraction studies. Acetylide complex $\underline{\mathbf{3 0}}$ readily undergoes protonation and acylation to give the vinylidene complexes $\underline{\mathbf{3 1}}$ and $\underline{\mathbf{3 2}}$, and it adds to the heterocummulenes TolN=C=O, $\mathrm{Ph}_{2} \mathrm{C}=\mathrm{C}=\mathrm{O}$, and $\mathrm{CO}_{2}$ to give, after protonation or alkylation, the vinylidene complexes $\underline{33}-\underline{35}$. These latter complexes likely form via the intermediacy of species $\underline{39}$. A similar conjugate addition occurs with trans-4-phenyl-3-buten-2-one to initially form $\underline{40}$ which gives the vinylidene complex $\underline{36}$ upon protonation. A significant finding is that complex $\underline{36}$ is

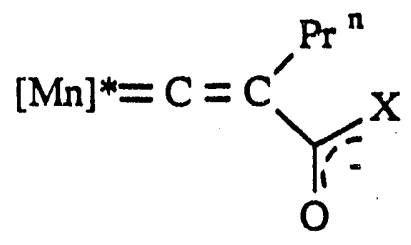

39: $\mathrm{X}=\mathrm{O}, \mathrm{NTol}$, or $\mathrm{CPh}_{2}$<smiles>CCCC(=C=C(C)C)C(=C=C(C)C)c1ccccc1</smiles>

$\underline{40}$

produced as a 9:1 mixture of the two possible diastereomers, implying that the chiral Mn center induces a high degree of stereospecificity during the nucleophilic addition step. The crys Ulographically characterized RR,SS diastereomer of $\underline{36}$ is the one expected to form if protonation occurred from the least sterically hindered side of the intermediate vinylidene complex and is presumably the diasteromer which is formed in excess.

One of the most surprising reactions observed for the acetylide complex $\underline{\mathbf{3 0}}$ was its cycloaddition with isobutylene oxide to give the carbene complex $\underline{37}$. Significantly, NMR data indicate that only a single pair (RR/SS or RS/SR) of diastereomers of $\underline{37}$ is produced in this reaction, implying that the stereochemical configuration at $\mathrm{Mn}$ dictates the configuration adopted at the chiral carbon of the cyclic carbene ligand. The methyl analogue of 37 prepared from [Cp'(CO) $\left.\left(\mathrm{PPh}_{3}\right) \mathrm{Mn}-\mathrm{C} \equiv \mathrm{CCH}_{3}\right]$; was similarly shown by ${ }^{1} \mathrm{H}$ NMR to form as a single diastereomeric pair, and this species was crystallographically characterized. The ORTEP drawing shown in Figure 5 indicates that it is the RS/SR pair that has formed, with the $\mathrm{CH}_{3}$ substituent and the bulky $\mathrm{PPh}_{3}$ ligand located on opposite sides of the planar metallacycle. As indicated in Scheme 8, oxidation of carbene complex $\underline{37}$ with $\mathrm{O}_{2}(\mathrm{~g})$ in dry $\mathrm{CH}_{2} \mathrm{Cl}_{2}$ releases the free lactone $\underline{38}$ which was isolated in modest yield. The stereochemical selectivity in the formation of 37 implies that lactone $\underline{38}$ would be produced is a single enantiomer if enantiomerically pure $\underline{29}$ were used in the initial reaction.

Figure 5

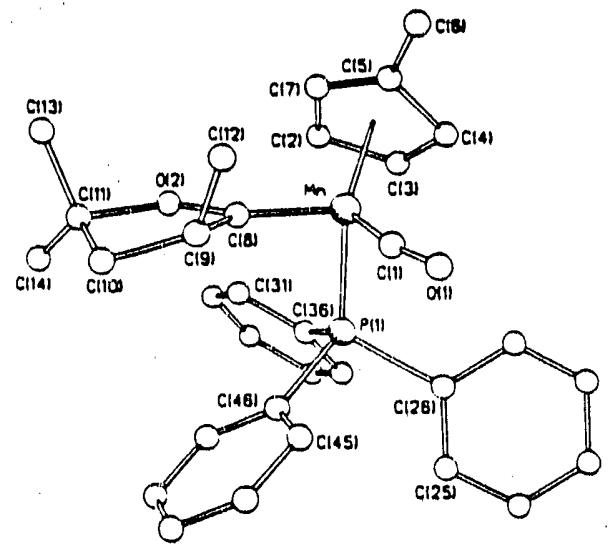


The formation of 37 and its methyl analogue likely proceeds via one of the mechanistic paths shown in Scheme 9 involving initial ring opening of the epoxide to give vinylidene

Scheme 9

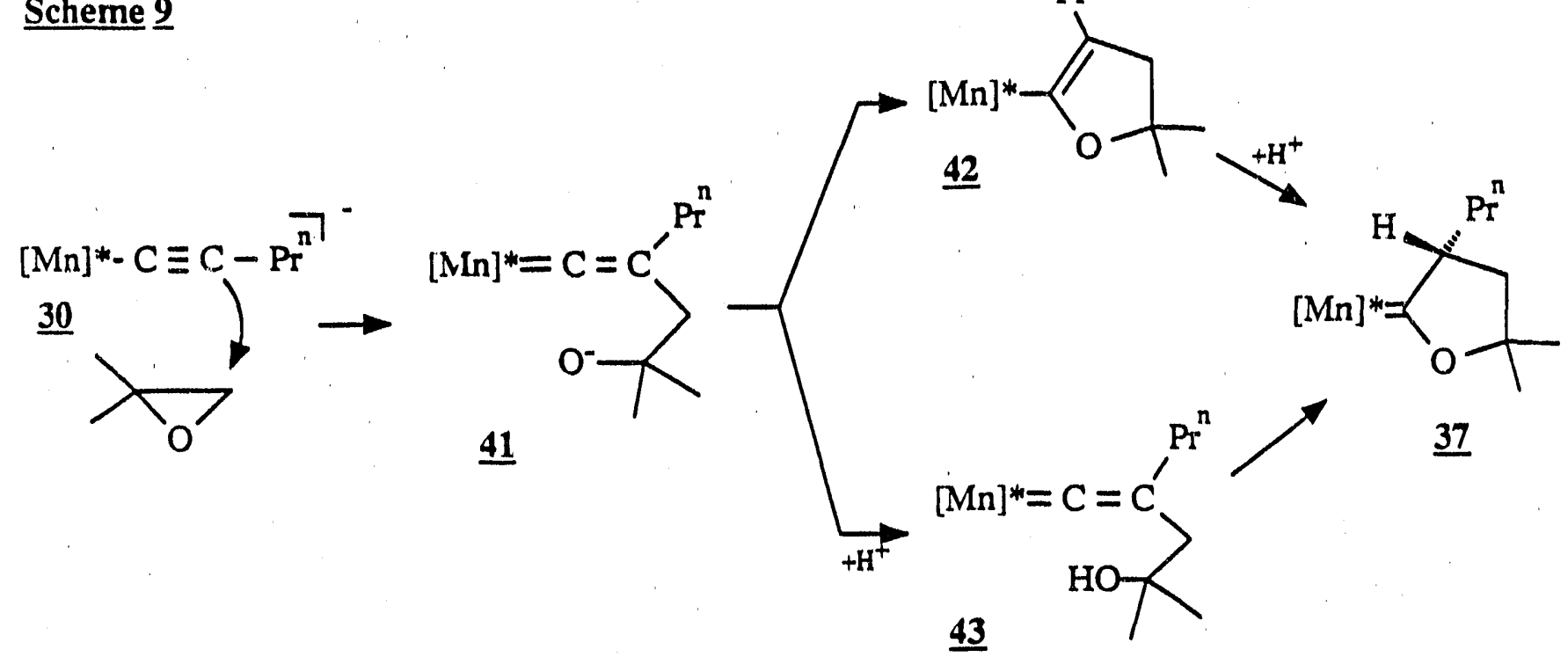

complex $\underline{41}$. Carbene complex $\underline{37}$ could then form by ring closure to give the vinyl complex $\underline{42}$ followed by protonation at the $\beta$-carbon. Alternatively, protonation of $\underline{41}$ could occur prior to ring closure to yield the vinylidene complex $\underline{43}$ from which $\underline{37}$ would result by addition of the $\mathrm{OH}$ bond across the $\mathrm{C}=\mathrm{C}$ bond of the vinylidene ligand, a characteristic reaction of vinylidene complexes. In this latter path, the chiral $\mathrm{Mn}$ center would dictate the stereochemistry of the tinal product by sterically controlling the transition state in the ring closure step. However, if the former path were operative, the stereochemistry of $\underline{\mathbf{3 7}}$ would be dictated by the protonation step, which could occur directly at the $\beta$ carbon or at the metal followed by hydride migration to the $\beta$-carbon.

The conjugate addition reactions summarized above for acetylide complex $\underline{30}$ are similar to transformations previously demonstrated for the conjugate bases of metal carbene complexes. ${ }^{20}$ The ability of the chiral manganese center in $\underline{30}$ to effectively dictate the chirality of the emerging stereocenter in the organic ligands of $\underline{\mathbf{3 6}}$ and $\underline{\mathbf{3 7}}$ imply that transformations like these may have potential use in stereospecific organic syntheses and could complement the many stereospecific transformations observed by Davies and co-workers for the related acyl complexes $\left[\mathrm{Cp}(\mathrm{CO})\left(\mathrm{PPh}_{3}\right) \mathrm{Fe}-\mathrm{C}(\mathrm{O}) \mathrm{CR}{ }^{\prime} \mathrm{R} .^{5}\right.$ Current efforts are focused on resolving carbene complex $\underline{29}$ into its separate enantiomers and on extending the addition and cycloaddition reactions reported herein to other organic sibstrates. 
VI. Halide-Pronnoted Carbonylation Reactions of Nitro- and Nitrosoaromatics. We have been interested in the metal catalyzed carbonylation of nitro- and nitrosoaromatics for some years because of the commercial interest in finding ways not involving the use of phosgene for the conversion of these chemicals into isocyanates and isocyanate derived products. There has been considerable speculation that cluster bound imido (nitrene) ligands are important in these reactions, and thus part of our studies have focussed on the carbonylation behavior of model organometallic compounds. In earlier work we showed that halides dramatically promote both the $\mathrm{CO}$ induced deoxygenation of nitroso reagents to form imido ligands on $\mathrm{Ru}_{3}$ clusters and the carbonylation of these ligands to form isocyanates, eq. $14 .^{21}$ These reactions were suggested to

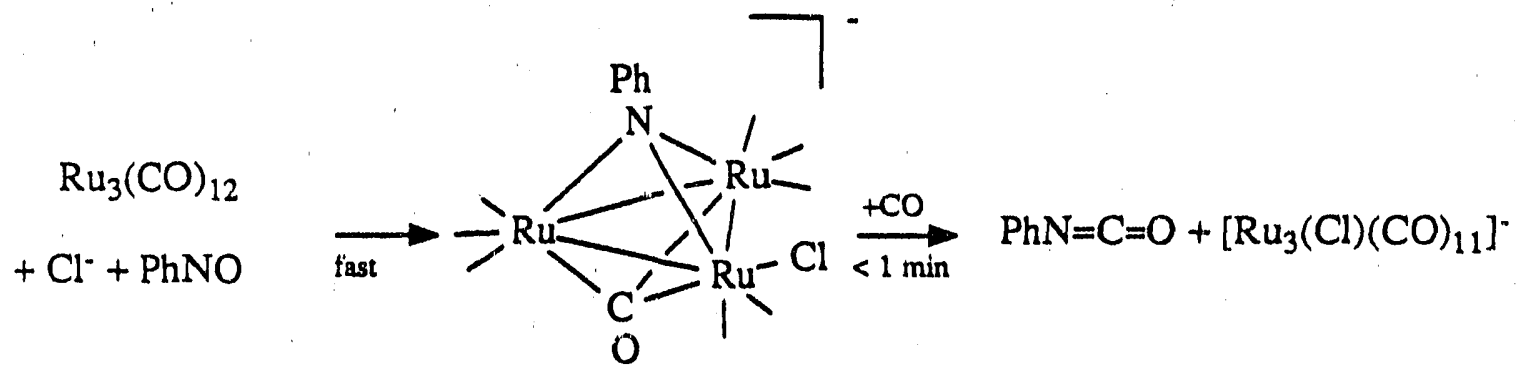

model some of the transformations which occur in Chini's $\mathrm{Ru}_{3}(\mathrm{CO})_{12}$ catalyzed and chloride-promoted carbonylation of $\mathrm{PhNO}_{2}$ in the presence of methanol to form $\mathrm{N}$-phenyl methylcarbamate. ${ }^{22}$ As a continuation of these studies, and in a collaborative effort with Duane Dombek at Union Carbide, we filled in several of the missing pieces of the puzzle of the reactions which occur when halides are added $t 5$ solutions of the clusters $\mathrm{Ru}_{3}(\mathrm{CO})_{12}$ and $\mathrm{Fe}_{3}(\mathrm{CO})_{12}$. That work is described in ref 23.

Also, as part of these studies we had prepared the heteronuclear imido clusters $\mathrm{FeRu}_{2}\left(\mu_{3}-\mathrm{NPh}\right)(\mathrm{CO})_{10}$ and $\mathrm{Fe}_{2} \mathrm{Ru}\left(\mu_{3}-\mathrm{NPh}\right)(\mathrm{CO})_{10}{ }^{21}$ and observed that they showed a greatly enhanced reactivity towards $\mathrm{CO}$ than did the homonuclear species $\mathrm{Ru}_{3}\left(\mu_{3}-\mathrm{NPh}\right)(\mathrm{CO})_{10}$. This led us to examine mixed $\mathrm{Fe}_{3}(\mathrm{CO})_{12} / \mathrm{Ru}_{3}(\mathrm{CO})_{12}$ catalysts for nitroaromatic reactions, and in the presence of chloride we found that $\mathrm{Fe}_{3}(\mathrm{CO})_{12}$ significantly increases the catalytic activity of $\mathrm{Ru}_{3}(\mathrm{CO})_{12}$ in the carbonylation of nitrobenzene to form methyl $\mathrm{N}$-phenylcarbamate, even though $\mathrm{Fe}_{3}(\mathrm{CO})_{12}$ alone is inactive under the conditions used. At a constant catalyst concentration of $0.093 \mathrm{M}$, optimum activity was observed for an $\mathrm{Fe} / \mathrm{Ru}$ molar ratio of $2: 1$. A similar synergistic $\mathrm{Fe} / \mathrm{Ru}$ behavior was observed for the chloride promoted reduction of nitrobenzene to aniline using $\mathrm{CO} / \mathrm{H}_{2} \mathrm{O}$ mixtures and for the water-gas shift reaction. The latter $\mathrm{Fe} / \mathrm{Ru}$ synergistic effect is know from the studies of Peter Ford, although the effect of chloride had not been previously observed. We have proposed a unified series of mechanisms for these three different but related catalytic reactions and an explanation for the $\mathrm{Fe} / \mathrm{Ru}$ synergistic effect which will be detailed in the complete paper on this work which is about to be submitted. 


\section{REFERENCES}

1. Casey, C. P.; Bunnell, C. A.; Calabrese, J. C. J. Ar, Chem. Soc. 1976, 98, 1166.

2. Sheridan, J. B.; Geoffroy, G. L.; Rheingold, A. L. J.Am. Chem. SoC. 1987, 109, 1584.

3. a) Sheridan, J. B.; Johnson, J. R.; Handwerker, B. M.; Geoffroy, G. L.; Rheingold, A. L. Organometallics 1988, Z, 2404. b) Geoffroy, G. L.; Sheridan, J. B.; Bassner, S. L.; Kelley, C. Pure Appl. Chem. 1989, 61, 1723.

4. a) Fischer, E. O.; Meineke, E.; Kreissl, F. R. Chem. Ber 1977, 110, 1140. b) Fischer, E. O. J. Chen, K. Scherzer. J. Organomet. Chem. 1983, 253, 231. c) Fischer, E. O.; Stueckler, P.; Kreissl, F. R. J. Organomet. Chem. 1977, 129, 197.

5. For a review see: Davies, S. G.; Dordor-Hedgecock, I. M.; Easton, R. J. C.; Preston, S. C.; Sutton, K. H.; Walker, J. C. Bull. Soc. Chim. France 1987, 4, 608.

6. Bastner, S. L.; Sheridan, J. B.; Kelley, C.; Geoffroy, G. L. Organometallics 1989, \&, 2121.

7. Geoffroy, G. L.; Sheridan, J. B.; Bassner, S. L., Kelley, C. Pure Appl. Chem. 1989, 61, 1723.

8. Stufkens, D. J.; Sheridan, J. B.; Geoffroy, G. L. Inorg. Chem. submitted for publication.

9. Brunner, H.; Langer, M. J.Organomet. Chem. 1973, 54, 221.

10. See for example: a) Semmelhack, M. F.; Tamura, R. J. J.Am. Chem. Soc. 1983, 105, 4099. b) Buhro, W. E.; Wong, A.; Merrifield, J. H.; Lin, G. Y.; Constable, A. C.; Gladysz, J. A. Organometallics 1983, 2, 1852. c) Powell, J ; Farrar, D. H.; Smith, S. J. Inorg. Chim. Acta 1984, 85, L23. d) Fischer, E. O.; Reitmeier, R; Ackerman, K. Z. Naturforsch. 1984, 39b, 668. e) Corey, E. J.; Kirst, H. A.; Katsenellenbogen, J. A. J. Am. Chem. Soc. 1970, $92,6314$.

11. Mirkin, C. A.; Lu, K.-L., Geoffroy, G. L.; Staley, D.; Rheingold, A. L., J. Am. Chem. Soc. 1989, $\underline{111}, 7279$.

12. a) Han, S. H.; Geoffroy, G. L.; Rheingoid, A. L. Organometallics 1987, $\underline{6}$, 2380. b) Nuel, D.; Dahan, F.; Mathieu, R. Organometallics 1986, 5, 1278. c) Dickson, R. S.; Nesbit, R. J.; Pateras, H.; Baimbridge, W.; Patrick, J. M.; White, A. H. Organometallics 1985, 4, 2128. d) for mononuclear metalla-pyrrolinone complexes see: Hoberg, H.; Hernandez, E.; Guhl, D. $\underline{J}$. Organomet. Chem. 1988, 339, 213 and references therein.

13. Schmidbaur, H. Angew. Chem. Int. Ed. Engl. 1983, 22, 907.

14. Sumner, C. E., Jr.; Collier, J. A.; Pettit, R. Organometallics 1982, 1, 1350.

15. Mirkin, C. A.; Lu, K.-L.; Snead, T. E.; Geoffroy, G. L.; Rheingold, A. L. J.Am. Chem. Soc. 1990, $\underline{112}, 2809$.

16. Roper, M.; Strutz, H.; Keim, W. J. Organomet. Chem. 1981, 219, C5.

17. Lavigne, G.; Kaesz, H. D. in Metal Clusters in Catalysis; Knozinger, H.; Gates, B. C.; Guczi, L., Eds.; Elsevier: Amsterdam, 1986; pp 68-69.

18. Blake, A. J.; Cockman, R. W.; Ebsworth, E. A. V.; Holloway, J. H. J. Chem. Soc., Chem. Comi'un. 1988, 529.

19. Lugan, N.; Kelley, C.; Terry, M. R.; Geoffroy, G. L.; Rheingold, A. L. J. Am. Chem. Soc., 1990, 
$112,3220$.

20. a) Casey, C. P.; Anderson, R. L. J. Organomet. Chem. 1974, 73, C28. b) Casey, C. P.; Brunsvold, W. R.; Scheck, D. M. Inorganic Chem. 1977, 16, 3059.

21. a) Han, S. H.; Geoffroy, G. L.; Rheingold, A. L. Inorg. Chem. 1987, 26, 3426. b) Han, S.-H.; Song, J.-S.; Macklin, P. D.; Nguyen, S. T.; Geoffroy, G. L. Rheingold, A. L. Organometallics 1989, $\underline{8}, 2127$.

22. a) Cenini, S.; Crotti, C.; Pizzotti, M.; Porta, F. J. Org. Chem. 1988, $\underline{53}$, 1243. b) Cenini, S.; Pizzotti, M.; Crotti, C.; Porta, F.; Monica, G. L. J. Chem. Soc., Chem. Commun. 1984, 1286.

23. Han, S.-H.; Geoffroy, G. L.; Dombek, B. D.; Rheingold, A. L. Inorg. Chem. 1988, 27, 4355. 

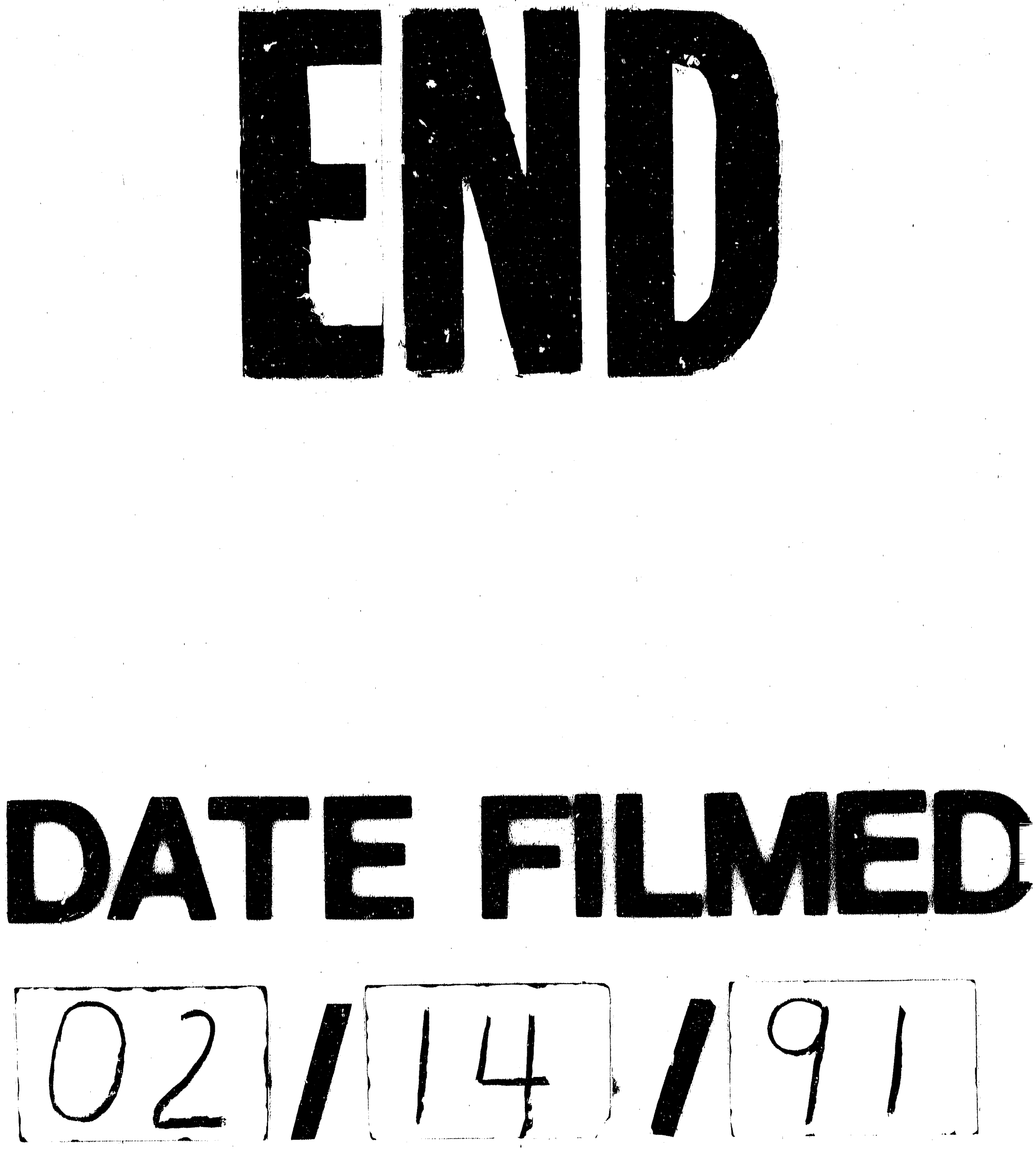
